\title{
Growth Hormone Secretagogue Receptor Dimers: A New Pharmacological Target ${ }^{1,2,3}$
}

\author{
Martin Wellman and Alfonso Abizaid
}

DOI:http://dx.doi.org/10.1523/ENEURO.0053-14.2015

Department of Neuroscience, Carleton University, Ottawa, Ontario, Canada, K1S 5B6

\begin{abstract}
The growth hormone secretagogue receptor (GHSR1a), the target of the ghrelin peptide, is widely distributed throughout the brain, and, while studies have often reported very low or absent levels of central ghrelin, it is now known that GHSR1a, even in the absence of a natural ligand, has physiological roles. Not only do these roles originate from the receptor's constitutive activity, but recent data indicate that GHSR1a dimerizes with a wide array of other receptors. These include the dopamine 1 receptor (D1R), the dopamine 2 receptor (D2R), the melanocortin-3 receptor (MC3R), the serotonin $2 \mathrm{C}$ receptor $\left(5-\mathrm{HT}_{2 \mathrm{C}}\right)$, and possibly the cannabinoid type 1 receptor (CB1). Within these dimers, signaling of the protomers involved are modified through facilitation, inhibition, and even modification of signaling pathways resulting in physiological consequences not seen in the absence of these dimers. While in some cases the ghrelin peptide is not required for these modifications to occur, in others, the presence is necessary for these changes to take effect. These heterodimers demonstrate the broad array of roles and complexity of the ghrelin system. By better understanding how these dimers work, it is hoped that improved treatments for a variety of disorders, including Parkinson's disease, schizophrenia, addiction, obesity, diabetes, and more, can be devised. In this review, we examine the current state of knowledge surrounding GHSR heterodimers, and how we can apply this knowledge to various pharmacological treatments.
\end{abstract}

Key words: G protein-coupled receptor; ghrelin; growth hormone secretagogue receptor; pharmacology; receptor dimerization

\section{Significance Statement}

The growth hormone secretagogue receptor, a key component of the ghrelin system, is important in many processes, including feeding behavior, stress, and reward. Recent data have revealed a variety of receptors that show the ability to dimerize with the ghrelin receptor, resulting in signal modulation, alterations in signaling cascades, and changes in trafficking and internalization of both protomers of the dimer complex. Here, we summarize the state of knowledge surrounding ghrelin receptor dimerization, along with potential treatments that arise from this knowledge for a variety of disorders, demonstrating the importance of understanding these dimer complexes.

\section{Introduction}

It has been 15 years since the discovery of ghrelin, a peptide hormone related to, among others, energy bal-

Received November 7, 2014; accepted April 7, 2015; First published April 14, 2015.

${ }^{1}$ The authors report no financial conflicts of interest. ance, feeding, stress, anxiety, and reward. Since its discovery, this hormone has led to a staggering number of

\footnotetext{
${ }^{2}$ Author contributions: M.W. and A.A. designed research; M.W. and A.A. performed research; M.W. and A.A. analyzed data; M.W. and A.A. wrote the paper.

${ }^{3}$ This work was supported by the Natural Sciences and Engineering Research Council of Canada, Ontario Graduate Scholarship (M.W.) and the Canadian Institutes of Health Research, Canada Foundation for Innovation (A..A.).
} 
studies, particularly in response to the current obesity epidemic found throughout modern society. These studies have been prompted by ghrelin's role as an orexigenic peptide, leading to increased feeding and adiposity, along with its role in diabetes. In general, three components of the ghrelin system have been targeted in the search for an elusive pharmacological compound that will contribute to weight loss. These are: (1) ghrelin itself, particularly its active esterified form: acylated ghrelin; (2) ghrelin O-acyltransferase (GOAT), the enzyme that acylates ghrelin, thus allowing it to bind to its receptor; and finally (3) the ghrelin receptor: GHSR1a.

While these three components are all directly related to ghrelin, one cannot deny the complex interrelationships between ghrelin and the multitude of other systems beyond simply the typical endocrine and feeding effects of this peptide. In line with this is an important concept in the study of G protein-coupled receptors (GPCRs): the idea of receptor oligomerization, in which GPCRs interact with other GPCRs in close proximity, resulting in physical association with possible conformational changes as well as changes in intracellular signaling and/or ligand binding. On top of this, dimerization may result in facilitation or inhibition of the protomers involved, as well as changes in surface expression, internalization, and trafficking.

Not only is ghrelin linked to obesity and diabetes, but studies have also shown a role in stress, anxiety, depression, and more (Lutter et al., 2008; Zheng et al., 2009; Patterson et al., 2010). Due to its roles in such a broad array of systems, targeting the ghrelin receptor with agonists or antagonists will not only affect the phenomenon of interest, such as feeding, but will also affect the other systems in which ghrelin is involved, leading to unwanted side effects. The ability to target only a subset of ghrelin receptors is a desirable goal that would hopefully minimize side effects and maximize treatment. By understanding the roles of receptor dimers, one would hope that designed drugs that target a specific dimer would be beneficial in pharmacological treatment. Such a dimer involving GHSR would be expected to have a more specific role than that of the ghrelin receptor in general. In addition to this, understanding how receptors are modified with dimerization can help us better understand how to treat certain disorders, providing hints for combinations of drugs that may synergistically amplify the desired effect or allow for a reduced dosage of certain medications with the goal of reducing intensity of side-effects.

In this review, we will examine the phenomenon of receptor dimerization with a focus on the role of the ghrelin receptor in such dimers and how this knowledge can aid in devising improved treatments for such disor-

Correspondence should be addressed to Martin Wellman, Department of Neuroscience, Carleton University, 1125 Colonel by Drive, Life Sciences Research Building, Ottawa, Ontario, Canada K1S 5B6. Tel. 613-816-2726. E-mail: martinwellman@gmail.com

DOI:http://dx.doi.org/10.1523/ENEURO.0053-14.2015

Copyright (C) 2015 Wellman and Abizaid

This is an open-access article distributed under the terms of the Creative Commons Attribution 4.0 International, which permits unrestricted use, distribution and reproduction in any medium provided that the original work is properly attributed. ders as Parkinson's disease, schizophrenia, obesity, depression, and diabetes. At present, dimers between the GHSR1a and the D1R, D2R, 5- $\mathrm{HT}_{2 \mathrm{C}}, \mathrm{MC} 3 \mathrm{R}$, and possibly the CB1 receptors have been identified, and no doubt more interactions will be found further down the road.

\section{A Short History of GPCR Oligomerization}

It has been known for over three decades that many membrane proteins exist as dimers or higher-order oligomeric structures (Klingenberg, 1981). Despite this, it was debated whether GPCRs in particular act solely as monomeric structures or if they oligomerize to form complexes with different characteristics from its constituent parts. While crosstalk between signaling cascades was acknowledged, actual allosteric interactions remained an area of debate. Some data suggests that the area accessible to G-proteins on the receptor is insufficient for transduction of the receptor signal to the relatively large trimeric G-protein complex (Park et al., 2004). Similarly, many non-GPCR membrane proteins also appear too small to interact with their proper ligands. Such proteins include the $\mathrm{Na}^{+}-\mathrm{K}^{+}$ATPase, the ADP/ATP carrier, and the glucose carrier (Klingenberg, 1981). While dimerization and oligomerization of integral membrane proteins remained a generally accepted concept, translating this to GPCRs remained elusive (Klingenberg, 1981).

The first identified dimerization of GPCRs involved homodimers. These included the $\delta$-opioid (Cvejic and Devi, 1997), metabotropic glutamate (Romano et al., 1996), and $\beta_{2}$ adrenergic (Hebert et al., 1996) receptors. Shortly after the discovery of these homodimers, Jones et al. (1998) identified the first GPCR heterodimer and described it as an obligate heterodimer, consisting of the complex formed by a GABA $A_{B} R 1$ and a GABA $A_{B} R 2$ protomer (Jones et al., 1998; Kaupmann et al., 1998; White et al., 1998). These two receptors were believed to interact through conserved coiled-coil domains in the intracellular C-termini, a phenomena that was later verified (Kammerer et al., 1999; Kuner et al., 1999). Margeta-Mitrovic et al. (2000) identified a C-terminal RSRR retention motif in $G A B A_{B} R 1$ that retains the receptor on the endoplasmic reticulum, thus preventing surface expression. Interaction with a $\mathrm{GABA}_{\mathrm{B}} \mathrm{R} 2$ through each partners' C-terminal coiled-coils masks the retention motif, thus allowing surface expression of the heterodimer. In addition, interaction with the intracellular G-protein for signal transduction appeared to be reliant on the $\mathrm{GABA}_{\mathrm{B}} \mathrm{R} 2$ protomer, with ligand binding reliant on the $\mathrm{GABA}_{\mathrm{B}} \mathrm{R} 1$ protomer (MargetaMitrovic et al., 2000; Robbins et al., 2001). These data demonstrate the obligate heterodimer nature of the $\mathrm{GABA}_{\mathrm{B}}$ receptor.

\section{Detecting Oligomerization}

There is some ambiguity when it comes to defining and identifying oligomerization. Often, receptors are coexpressed on the same neuron but do not form a multimeric complex with unique characteristics. While signaling may overlap and receptors may be in close proximity, the group of receptors might not necessarily generate a functional receptor complex. In order to remove ambiguity, the International Union of Basic and Clinical Pharmacology suggested a set of requirements in order for a group of 


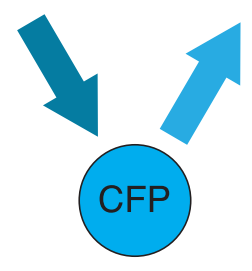

No FRET
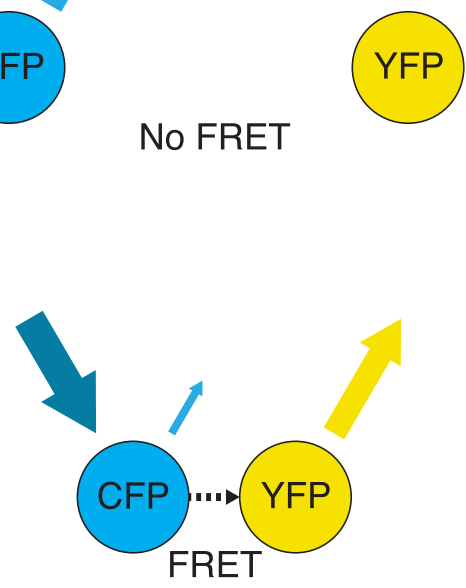
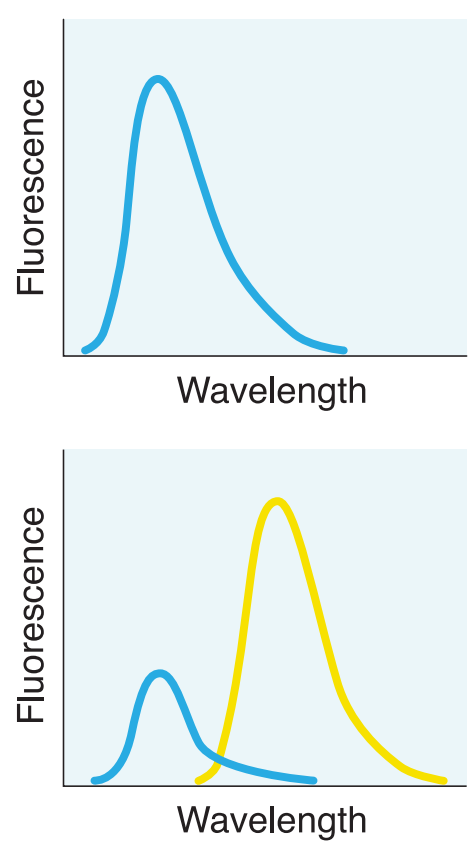

Figure 1 Fluorescence resonance energy transfer. In this FRET example, cyan fluorescent protein (CFP) acts as the donor and yellow fluorescent protein (YFP) as the acceptor. When the two fluorophores are separated by a considerable distance, exposing the sample to light with the excitation frequency for CFP results in an emission spectrum corresponding to CFP only, with no contribution from the acceptor (top). When the two fluorophores are nearby (typically in the range of 10 to $100 \AA$ ), exposing the sample to the same light results in a nonradiative energy transfer from CFP to the nearby YFP acceptor, causing YFP to emit at its emission frequency (bottom). At the same time, due to the transfer of energy, emission from CFP is considerably reduced. Detection of YFP emission indicates that fluorescence resonance energy transfer has occurred between the two fluorophores as a result of their close proximity. By fusing these fluorophores to the receptors of interest, dimerization can be implied if fluorescence resonance energy transfer is observed.

receptors to be considered as part of an oligomeric complex. We refer the reader to Pin et al. (2007) for a detailed description of these requirements.

One of the most common techniques in detecting oligomerization is coimmunoprecipitation, where pulling down one protomer also pulls down its dimer partner. There are, however, drawbacks to this technique. For instance, coimmunoprecipitation cannot be used to examine interactions in living cells in real time. In addition, aggregation as a result of the solubilization step is a common problem, resulting in false positives (Szidonya et al., 2008). Another source of false positives is the high levels of receptor expression typically used with this technique, which can lead to nonphysiological dimerization simply as a result of overexpression and crowding (Szidonya et al., 2008). In contrast, dimers may be disrupted during preparation of the samples and give false negatives (Szidonya et al., 2008). Finally, raising antibodies directly against GPCRs is a task that has proven to be quite difficult (Fredholm et al., 2007), although tagging alternatives are available.

A technique that avoids many of the problems of coimmunoprecipitation is resonance energy transfer (RET) and its derivative techniques (Fig. 1). Perhaps one of its most powerful advantages is its ability to measure dimerization in real-time in living cells. While there are many techniques related to RET, they all involve the nonradiative transfer of energy (on the nanoscale range) between a donor and a nearby acceptor, which have been fused to the two re- ceptors of interest. This transfer is measured by examining the emission of energy from the acceptor after it has accepted the transfer from the donor. For example, in the case of fluorescence resonance energy transfer (FRET), the donor is excited by light of a certain wavelength. If the donor is in close proximity to the acceptor, this energy is transferred and then emitted at a characteristic wavelength by the acceptor, which can be measured by scanning spectroscopy, a microplate reader, or microscopy. In the case of bioluminescence resonance energy transfer (BRET), a donor such as the enzyme Renilla luciferase is used.

While RET-based techniques are considerably more powerful than coimmunoprecipitation, there are some disadvantages to this technique. Of particular importance is the requirement for a proper orientation of the dipoles in order for the energy transfer to occur (Szidonya et al., 2008). Along with this, the efficiency of the transfer is inversely proportional to the sixth power of the distance between the dipoles, demonstrating extreme sensitivity of the technique to distance (Esen-Danaci et al., 2008). These restrictions require that the donor and acceptor have considerable flexibility in movement in order to acquire the correct orientation and distance.

Along with FRET and BRET, there are other derivatives of RET. For a more detailed discussion of coimmunoprecipitation and RET as they relate to GPCR oligomerization, we refer the reader to Szidonya et al. (2008). 


\section{Signaling and distribution of the GHSR1a}

The GHSR1a was first identified in 1996 by a team of researchers who were looking for a way to improve growth hormone release (Howard et al., 1996), and this discovery was followed by the identification of its natural ligand, ghrelin, a peptide hormone produced by the stomach (Kojima et al., 1999). Interestingly, ghrelin requires acylation on its serine-3 residue by the enzyme GOAT in order for the peptide to bind to GHSR1a (Kojima et al., 1999; Gutierrez et al., 2008; Yang et al., 2008).

Signal transduction of GHSR1a primarily occurs through the $\mathrm{G}_{\mathrm{q} / 11}$ pathway (Camiña et al., 2007). This pathway involves activation of phosphatidylinositol phospholipase C (PIPLC), phosphatidylinositol 4,5-bisphosphate $\left(\mathrm{PIP}_{2}\right)$ and inositol trisphosphate $\left(\mathrm{IP}_{3}\right)$, ultimately resulting in mobilization of intracellular $\mathrm{Ca}^{2+}$ stores (Camiña et al., 2007). In addition to the $G_{q / 11}$ pathway, the $G_{i / o}$ pathway has also been shown to be recruited by the ghrelin receptor. In rat and human tissue, high signals for GHSR1a mRNA are found expressed in several hypothalamic nuclei, the pituitary, and the dentate gyrus of the hippocampus, with additional yet reduced signals in CA2 and CA3 of the hippocampus, the substantia nigra, the ventral tegmental area, and the median raphe nuclei (Guan et al., 1997; Willesen et al., 1999; Gnanapavan et al., 2002; Zigman et al., 2006). Of particular interest is the arcuate nucleus, an area more open to peripheral signals due to the reduced blood-brain barrier at the median eminence. Indeed, many labs have measured high levels of GHSR1a mRNA in the arcuate nucleus (Howard et al., 1996; Guan et al., 1997; Tannenbaum et al., 1998; Willesen et al., 1999; Mitchell et al., 2001; Zigman et al., 2006). This area's important role in feeding is undeniable, with extensive connections to all other areas of the hypothalamus. While GHSR1a activity in the hypothalamus is likely heavily involved in homeostatic mechanisms, its presence in extra hypothalamic regions, including a number of limbic and midbrain structures like the ventral tegmental area (VTA), suggest that this receptor is associated in processes associated with learning and motivation (Abizaid et al., 2006; Abizaid and Horvath, 2008). Nevertheless, the entry of peripheral ghrelin into the brain is limited and potentially binds only to areas of the brain that are less protected by the blood-brain barrier like the arcuate and the area postrema in the brain stem (Banks et al., 2002; Cabral et al., 2013). Furthermore, evidence for a central source of ghrelin remain questionable, with only very low levels being found in the hypothalamus (Hosoda et al., 2000; Cowley et al., 2003). Without the natural ligand for the GHSR1a in many parts of the brain, the various roles of this receptor centrally remain uncertain.

Studies identifying a high constitutive activity of the ghrelin receptor (Holst et al., 2003; Damian et al., 2011) suggested that expression of GHSR1a itself, without the need for binding, could have physiological significance. Regulation of this constitutive activity, either through allosteric interactions with other proteins, regulation of receptor internalization and trafficking, or modulation of transcription and translation, became an important area of research. In the absence of ghrelin, GHSR1a shows 50\% of its maximal ligand-stimulated activity through the $\mathrm{G}_{\mathrm{q} / 11}$ pathway (Holst et al., 2003). It is likely that overall changes in constitutive activity, in the absence of ghrelin, provide sufficient modulation of signaling pathways to demonstrate an important physiological effect. In line with this idea is a genetic study identifying a missense mutation, A240E located in the second extracellular loop, resulting in reduced constitutive activity and leading to familial short stature (Pantel et al., 2006). Importantly, this mutation did not display reduced ghrelin binding. While the phenotype of this mutation may be due to both peripheral and central actions, it demonstrates the importance of GHSR1a's constitutive activity. Furthermore, GHSR1a's constitutive activity has opened the door for investigation into the effects of inverse agonists, in particular [D-Arg ${ }^{1}$, D-Phe ${ }^{5}, \mathrm{D}-\operatorname{Trp}^{7,9}$, Leu ${ }^{11}$ ]-substance P (SP-analog), which has in turn provided hints to the structure and epitopes of the ghrelin receptor.

Despite these findings, the high levels of GHSR1a expression used in experiments identifying GHSR1a's constitutive activity may be the source of this unusually high basal activity. When expressed at the low levels representative of in vivo amounts, at least one laboratory has found that basal activity was not detectable (Kern et al., 2012). Furthermore, at the high expression levels used, GHSR1a homodimerization may be artificially enhanced. Whether homodimerization is required for constitutive activity is unknown, although GHSR1a homodimers have been detected. Indeed, while examining dimerization between the D2 receptor and GHSR1a, Kern et al. (2012) observed a FRET signal when CLIP-GHSR1a and SNAP-GHSR1a are overexpressed. Additionally, Jiang et al. (2006) observed GHSR1a homodimers in a HEK293-derived cell line by examining the BRET signal for GHSR1a-GFP/ GHSR1a-Rluc, with the ratio displaying a hyperbolic shape, suggesting dimerization rather than crowding. As Schellekens et al. (2013) put it, the GHSR1a is quite a "promiscuous" receptor, not only with other receptors but also with itself.

Data from Rediger et al. (2011), however, suggest that the constitutive activity of GHSR1a is not the result of dimerization. Using two naturally occurring mutations of GHSR1a that demonstrate reduced constitutive activity, Rediger et al. (2011) were still able to detect homodimerization. Furthermore, data from Holst et al. (2004) suggest that constitutive activity depends on several residues on the inner face of GHSR1a, which seem unlikely to be locations important for the dimerization interface. While this constitutive activity alone gives support to a role of GHSR1a centrally where only extremely low levels of ghrelin have been found (Hosoda et al., 2000; Cowley et al., 2003), more recent findings of GHSR1a heterodimerization reveal a whole slew of roles that the receptor plays in the brain, some of which do not require the presence of the ghrelin peptide. Understanding these dimers will provide insight into possible pharmacological interventions. 


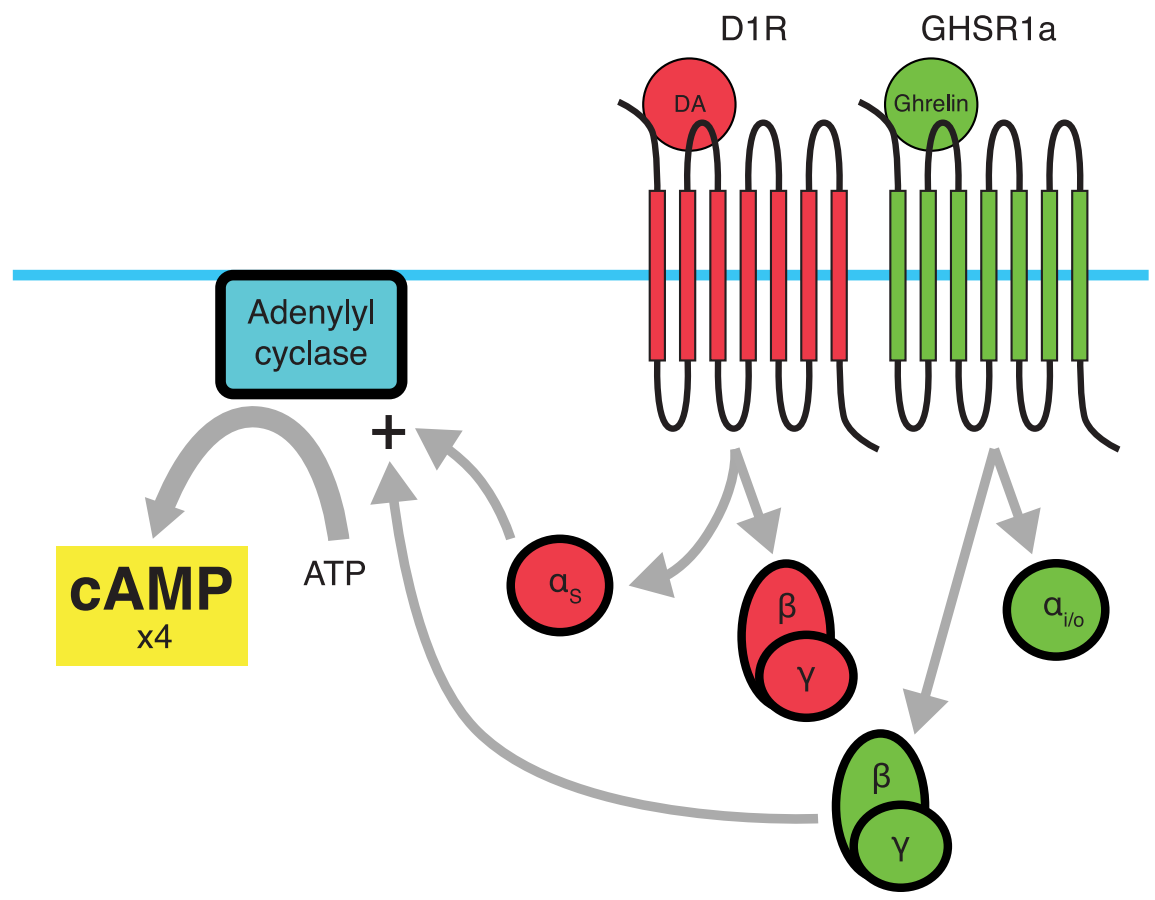

Figure 2 Dimerization between D1R and GHSR1a. When dimerized with D1R, GHSR1a switches G-protein coupling from $\mathrm{G}_{\mathrm{q} / 11}$ to $\mathrm{G}_{\mathrm{i} / \mathrm{o}}$. Coadministration of a D1R agonist with a GHSR1a agonist leads to a fourfold amplification of D1R-associated cAMP accumulation. It is believed that the $\mathrm{G}_{\beta \gamma}$ subunit associated with GHSR1a adopts a stimulatory role on adenylyl cyclase activity due to the proximity of the $\alpha_{\mathrm{S}}$ subunit derived from D1R's trimeric G-protein.

\section{GHSR1a dimerization with D1- and D2-like dopamine receptors}

The interaction between GHSR and dopamine receptors was first hypothesized given the coexpression of these receptors at a number of sites, including a number of brain regions associated with food intake and rewardseeking behaviors (Guan et al., 1997). The dopamine system is one of the most studied neurotransmitter systems, with dopamine being one of the earliest identified neurotransmitters due in large part to its pivotal role in the reward system, a system often described as being essential to all forms of life. In feeding behavior, enhanced dopaminergic activity induces rewarding effects and also enhances memory formation for events associated with reward (White, 1988, 1989; Centonze et al., 2001; Wise, 2006; Wise, 2008). One would intuitively suspect that ghrelin and dopamine interact with each other.

The group of dopamine receptors has two families: D1-like, which includes D1R and D5R, and D2-like, which includes D2R, D3R, and D4R. Jiang et al. (2006) demonstrated that, in the presence of both dopamine and ghrelin, the ghrelin receptor amplifies dopamine-induced CAMP accumulation via D1R. Subsequently, Kern et al. (2012) demonstrated that in the absence of ghrelin, GHSR1a oligomerizes with D2R and that this oligomerization is required for D2R's anorexigenic effects.

\section{GHSR1a dimerization with the D1R amplifies D1R signaling}

The D1 receptor has been localized to various regions of the brain, with an array of different functions, including but not limited to the substantia nigra and caudate-putamen (motor activity) (Double and Crocker, 1995; Centonze et al., 2003), prefrontal cortex and hippocampus (cognition, learning, and memory) (Sawaguchi et al., 1990; Sawaguchi and Goldman-Rakic, 1994; Williams and Goldman-Rakic, 1995; Otmakhova and Lisman, 1996; Matthies et al., 1997; Seamans et al., 1998; Granado et al., 2008), nucleus accumbens and olfactory tubercle (reward) (Kurumiya and Nakajima, 1988; Nakajima, 1989; Ikemoto et al., 1997; Ikemoto, 2003), and hypothalamus (feeding and reward) (Nakajima and McKenzie, 1986; Chen et al., 2014).

Coexpression of GHSR1a and D1R has been reported in the cortex, hippocampal structures, substantia nigra, midbrain, and ventral tegmental areas (Jiang et al., 2006). In HEK293 cells expressing D1R and GHSR1a, both a BRET signal and coimmunoprecipitation indicate dimerization between the two receptors (Jiang et al., 2006). As summarized in Figure 2, coadministration of dopamine and ghrelin to these cells show a fourfold amplification of D1R-associated cAMP signaling, with this amplification requiring both receptors and both ligands (Jiang et al., 2006). These data demonstrate dimerization in areas associated with mood, learning, and memory. Interestingly, when ghrelin is administered alone to cells coexpressing D1R and GHSR1a, no increase in cAMP accumulation is observed, while typical levels of $\mathrm{Ca}^{2+}$ accumulation associated with GHSR1a activation occur (Jiang et al., 2006). Despite this, the PKC inhibitor bisindolylmaleimide I (Bis) does not affect cAMP augmentation within the D1/GHSR1a dimer, while pertussis toxin, an inhibitor of 
the $G_{i / o}$ pathway, eliminates cAMP augmentation (Jiang et al., 2006). In addition to this, pertussis toxin administration in the absence of ghrelin does not affect dopamine-associated cAMP accumulation, which typically signals through $\mathrm{G} \alpha_{\mathrm{s}}$ and $\mathrm{G} \alpha_{\text {olf }}$ (Missale et al., 1998; Neve et al., 2004). These data suggest that the synergy between GHSR1a and D1R is due to GHSR1a switching from $\mathrm{G} \alpha_{\mathrm{q} / 11}$ coupling to $\mathrm{G} \alpha_{\mathrm{i} / \mathrm{o}}$ coupling, a $\mathrm{G}$-protein that is not associated with D1R or GHSR1a when expressed alone. In addition to this synergistic effect, cointernalization of D1R-GHSR1a is induced after stimulation by the $D_{1}$ agonist 6,7-ADTN hydrobromide or GHSR1a agonists (Schellekens et al., 2013). In effect, GHSR1a as well as D1R agonists can terminate the effect of the dimer partner's natural ligands through cointernalization.

An effective way to test the role of the D1R-GHSR1a dimer in behaviors associated with ghrelin would be by way of mutations in GHSR1a or D1R that may negatively affect heterodimerization. For example, in the $\mathrm{GABA}_{\mathrm{B}}$ receptor, heterodimers associate through $\mathrm{C}$-terminal parallel coiled-coil $\alpha$-helices, and mutations in their primary structure can eliminate dimerization (White et al., 1998; Kammerer et al., 1999). A bioinformatics approach may help reveal more data regarding amino acid sequences involved in dimerization associated with GHSR1a, which may eventually lead to identification of polymorphisms that affect dimerization.

Jiang et al. (2006) proposed a molecular mechanism for the synergistic effect of D1R-GHSR1a dimerization on cAMP accumulation. In the case of D1R, G-protein activation involves dissociation of the $\mathrm{G} \alpha_{\mathrm{s}}$ and $\mathrm{G} \beta \gamma$ subunits. $\mathrm{G} \alpha_{\mathrm{s}}$ stimulates membrane-associated adenylyl cyclase (AC) activity. The $\mathrm{G} \beta \gamma$ subunit is believed to play a modulatory role, with a stimulating effect for $\mathrm{AC} 2, \mathrm{AC} 4$, and $A C 7$, and an inhibiting effect for $A C 1$ and $A C 8$ (Jiang et al., 2006). Interestingly, the $\mathrm{G} \beta \gamma$ subunit can only play a stimulatory role when associated with $\mathrm{G} \alpha_{\mathrm{S}}$. In the case of the D1R-GHSR1a heterodimer, it is believed that GHSR1a switches $\mathrm{G}$-proteins from $\mathrm{G} \alpha_{\mathrm{q} / 11}$ to $\mathrm{G} \alpha_{\mathrm{i}}$. Dissociation of the $G \beta \gamma$ subunit from $G \alpha_{i}$, which would normally inhibit cAMP accumulation through adenylyl cyclase, switches to a stimulatory role due to the activation induced by the nearby $\mathrm{G} \alpha_{\mathrm{S}}$ activity.

\section{GHSR1a dimerization with the D2 receptor: molecular and behavioral effects}

Like the D1 receptor, the D2 receptor has a broad distribution, with the two showing considerable overlap. This includes high levels of expression in the neostriatum, olfactory tubercle, substantia nigra, ventral tegmental area, and the nucleus accumbens (Meador-Woodruff et al., 1989). While the D1 receptor stimulates adenylyl cyclase activity, the D2 receptor inhibits it through a $\mathrm{G} \alpha_{\mathrm{i}}$ pathway (Missale et al., 1998; Neve et al., 2004).

Dimerization between D2R and GHSR1a has been demonstrated using FRET, with strong signals originating in hypothalamic cultures (Kern et al., 2012). This dimerization appears to induce a switch in intracellular signaling cascades in which administration of a dopamine agonist (quinpirole) alone leads to a rapid increase in $\mathrm{Ca}^{2+}$ levels, an effect not observed in preparations expressing $D 2 R$ in the absence of GHSR1a (Kern et al., 2012). This effect can be attenuated by administering the D2R-specific antagonist raclopride or the GHSR1a inverse agonist SP-analog (Kern et al., 2012).

Using a variety of inhibitors of second messenger signaling molecules, Kern and colleagues (2012) identified the pathway responsible for D2R-induced $\mathrm{Ca}^{2+}$ mobilization when dimerized with GHSR1a. This pathway included PLC-dependent activation through $\mathrm{G} \alpha_{\mathrm{i}}$ coupling, ultimately leading to release of $\mathrm{Ca}^{2+}$ from the endoplasmic reticulum via $\mathrm{IP}_{3}$ receptors (Fig. 3). Interestingly, by similarly inhibiting specific pathway components, it was shown that this signaling was dependent on $\mathrm{G} \beta \gamma$ subunits derived from D2R's $\mathrm{G} \alpha_{\mathrm{i} / \mathrm{o}}$, stimulating PLC activity. Furthermore, dimerization of D2R with a GHSR1a mutant lacking constitutive activity still displayed dopamineinduced $\mathrm{Ca}^{2+}$ mobilization, albeit considerably reduced, while two constitutively active mutants were absent in $\mathrm{Ca}^{2+}$ mobilization, suggesting that $\mathrm{Ca}^{2+}$ mobilization is independent of GHSR1a constitutive activity. In addition, inhibiting GHSR1a's $\mathrm{G} \alpha_{\mathrm{q}}$ using siRNA did not result in loss of dopamine-induced $\mathrm{Ca}^{2+}$ mobilization, but did significantly reduce ghrelin-induced $\mathrm{Ca}^{2+}$ mobilization. Overall, evidence suggests that GHSR1a's constitutive activity is not required for the alteration in D2R-mediated signaling. Perhaps the most striking results obtained by Kern et al. are the behavioral data examining the interaction between D2R and the GHSR1a in mice (Vucetic and Reyes, 2010; Kern et al., 2012). Cabergoline, a D2R-selective agonist, produces a dose-dependent suppression of food intake in wild-type mice and in ghrelin KO mice, but has no effect on food intake in GHSR KO mice (Kern et al., 2012). These data clearly show that the anorexigenic effects of cabergoline depend on GHSR1a and not on ghrelin, providing more evidence that GHSR1a has a central role even in the absence of the ghrelin peptide.

While these data are fascinating, a natural question that arises is what happens if ghrelin levels are allowed to increase? This examination may be subject to debate in the face of extremely low central ghrelin levels. There is a possibility, however, that certain manipulations such as stress or food restriction/deprivation may cause an increase in central ghrelin levels. If one were to examine the effects of elevated ghrelin levels, some interesting questions may be posed. As discussed, it appears that the D2R-induced anorexigenic effect of dopamine depends on the presence of GHSR1a. Kern et al. (2012) found cross-desensitization within the D2R-GHSR1a heteromer. Specifically, pretreatment with the GHSR1a agonist MK0677 or ghrelin for 30 min resulted in an attenuated response to dopamine, with $60-75 \%$ reduction in calcium mobilization. One way that this reduction might occur is through desensitization, disassociation, or cointernalization of the dimer. If ghrelin were to be present in the brain for a prolonged period of time, it would eventually attenuate the anorexigenic effect of D2 receptor through cross-desensitization. Interestingly, administration of the GHSR1a antagonist JMV2959 or the inverse agonist SPanalog also attenuate the anorexigenic effect caused by 


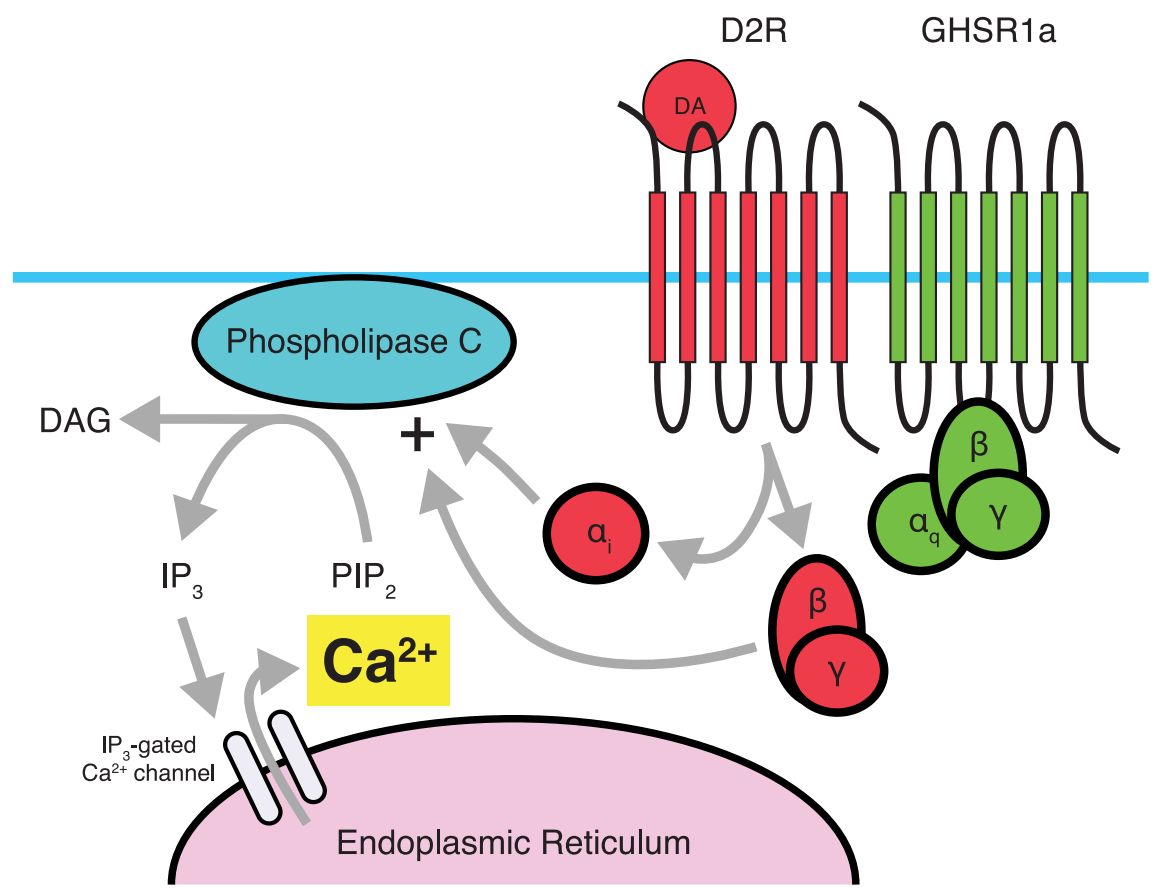

Figure 3 Dimerization between D2R and GHSR1a. Proposed signaling through D2R involves coupling to a $G_{i}$ pathway, which typically does not involve intracellular $\mathrm{Ca}^{2+}$ accumulation from the endoplasmic reticulum. Dimerization with GHSR1a, in the absence of a ghrelin ligand leads to a PLC-dependent accumulation of $\mathrm{Ca}^{2+}$. D2R's $\mathrm{G}_{\beta \gamma}$ subunit acts to stimulate PLC activity, and $\alpha_{\mathrm{i}}$ coupling by $\mathrm{D} 2 \mathrm{R}$ is also required for $\mathrm{Ca}^{2+}$ accumulation. In contrast, $\mathrm{G} \alpha$ activity associated with $\mathrm{GHSR} 1 \mathrm{a}$ is not required for D2R-induced Ca ${ }^{2+}$ accumulation. It is believed that the D2R-GHSR1a dimer is responsible for the anorectic effects of D2R agonists such as cabergoline.

D2 agonists, but in this case, the attenuation appeared immediately. The more immediate effects of GHSR receptor antagonist administration on dopamine's anorectic signaling deserves examination. During the period over which desensitization is being established, other signaling molecules and pathways may contribute to behavioral changes and examining the time frame of changes in the levels of relevant neurotransmitters may help tease apart the complexities associated with feeding regulatory systems.

\section{GHSR1a dimerization with the melanocortin-3 receptor amplifies MC3R and inhibits GHSR1a signaling}

Within the arcuate nucleus, most GHSR1a-expressing neurons coexpress MC3R, while a much smaller proportion of MC3R-expressing neurons coexpress GHSR1a (Rediger et al., 2009). Within this overlapping expression, Rediger et al. (2009) have identified MC3R-GHSR1a dimers using FRET. Typical signaling through MC3R involves a $\mathrm{G} \alpha_{\mathrm{s}}$ pathway leading to cAMP accumulation. Within this dimer, MC3R-associated CAMP accumulation is increased twofold while GHSR1a constitutive activity and ghrelin-induced activity, as measured by intracellular $\mathrm{Ca}^{2+}$ levels, are reduced by $40 \%$ (Fig. 4) (Rediger et al., 2009). Coadministration of $\alpha$-melanocyte-stimulating hormone $(\alpha-\mathrm{MSH})$ with ghrelin does not affect these changes in signaling (Rediger et al., 2009).

Much of our knowledge surrounding the MC3R derives from studies involving MC3R KO animals, which demonstrate increased adiposity, reduced lean mass, and in- creased feed efficiency, with mildly reduced or absent changes in caloric intake and normal metabolic rates (Butler et al., 2000; Chen et al., 2000). In wild-type animals, MC3R activation has been associated with anorectic effects (Fan et al., 1997; Thiele et al., 1998; Cowley et al., 1999).

In the absence of MC3R, the inhibition on GHSR1a is absent, resulting in an increase in GHSR1a signaling. While this may explain in part the increase in fat mass in $M C 3 R^{-1-}$ animals, it does not explain the hypophagia sometimes found in these animals (Chen et al., 2000). If one ignores the traditional caveats of developmental adaptions in knock-out animals, this suggests that ghrelin's ability to increase feeding, particularly of food with high fat content, might be dependent on MC3R, with the possibility that ghrelin-induced, feeding-independent adiposity does not. Indeed, it has been shown that MC3R $K O$ animals do not display ghrelin-induced hyperphagia (Shaw et al., 2005). Complicating matters, signaling downstream of GHSR1a involves amplification of agoutirelated peptide (AgRP), which is an inverse agonist of MC3R (Breit et al., 2006; Tao et al., 2010). To the best of our knowledge, no study has examined how AgRP affects the MC3R-GHSR1a heterodimer.

Additionally, when HEK293 cells are cotransfected with MC3R and a GHSR1a mutant showing impaired or absent constitutive activity, heterodimerization still occurs but amplification of $\alpha$-MSH-induced cAMP accumulation is lost, suggesting that the twofold increase in cAMP accumulation depends on GHSR1a basal activity (Rediger 

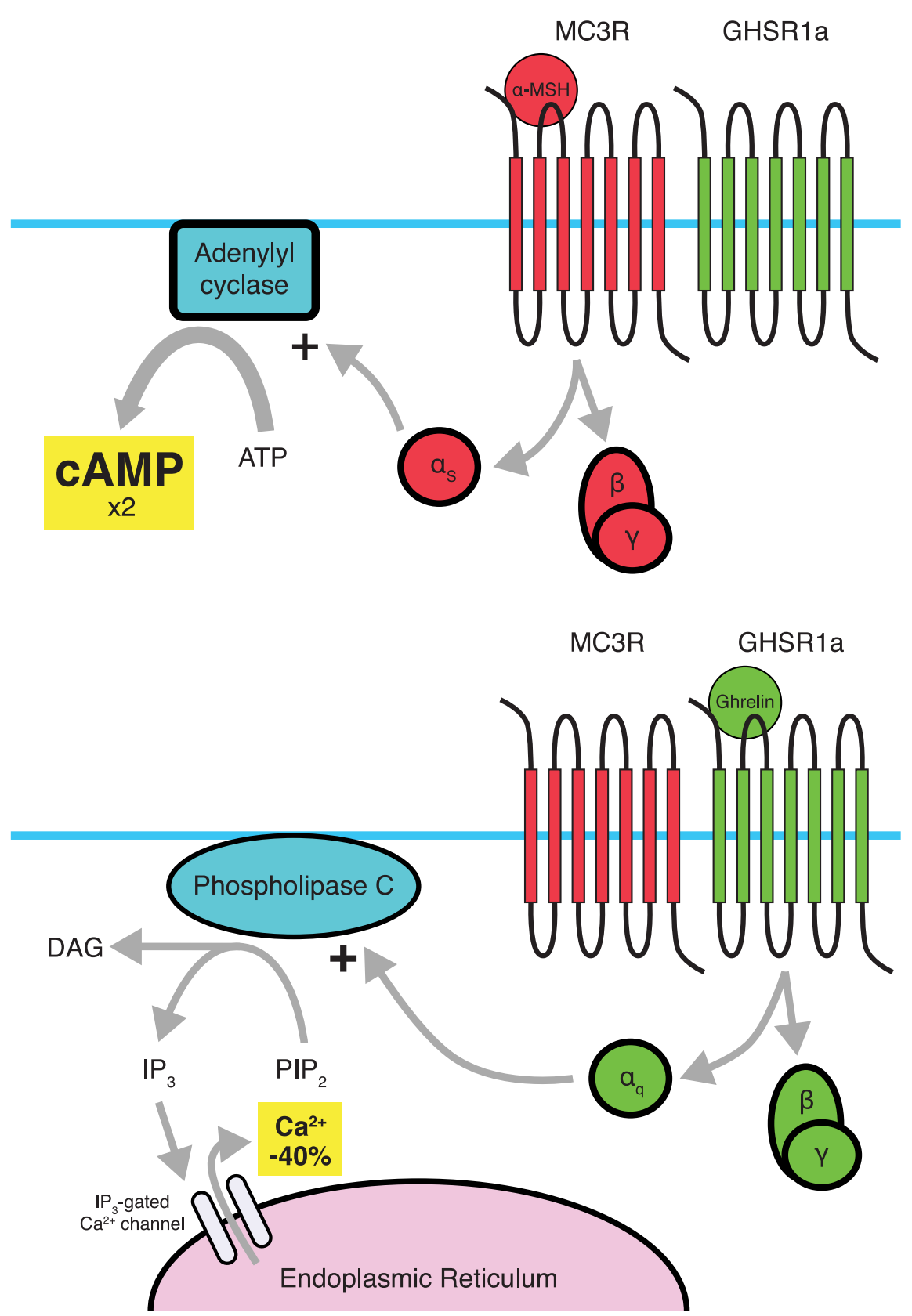

Figure 4 Dimerization between MC3R and GHSR1a results in amplification of MC3R signaling and attenuation of GHSR1a signaling. While it is believed that the pathways involved are not changed, changes in the amplitude of the signals occur. Dimerization with stimulation of MC3R leads to a twofold amplification of MC3R-induced cAMP accumulation (top), while the GHSR1a protomer shows a ligand-dependent as well as ligand-independent $40 \%$ reduction in $\mathrm{Ca}^{2+}$ accumulation when dimerized with $\mathrm{MC3R}$ (bottom). Amplification of MC3R signaling appears to be dependent on GHSR1a's constitutive activity.

et al., 2011). This effect of GHSR1a's constitutive activity again demonstrates that the receptor's basal activity may show physiological consequences without the need for the ghrelin peptide.

In examining the GHSR1a-MC3R dimer, Schellekens et al. (2013) demonstrated that activation by ghrelin or the synthetic ghrelin agonist MK-0677 causes an increase in internalized dimers, yet no significant changes are observed when treated with the MC3R agonist $\left[\mathrm{Nle}^{4}, \mathrm{D}\right.$ $\left.\mathrm{Phe}^{7}\right]-\alpha-\mathrm{MSH}$. Interestingly, under basal conditions when expressed with MC3R, a higher level of GHSR1a internalization is found (Schellekens et al., 2013). These additionally internalized receptors are for the most part dimerized with MC3R (Schellekens et al., 2013), suggesting that dimerization with MC3R may not only lead to reduced efficiency of GHSR1a signaling, but also to reduced surface expression of the receptor.

While GHSR1a constitutive activity is required for amplification of MC3R signaling, it has minimal effect on GHSR1a-MC3R dimer internalization, as treatment with 


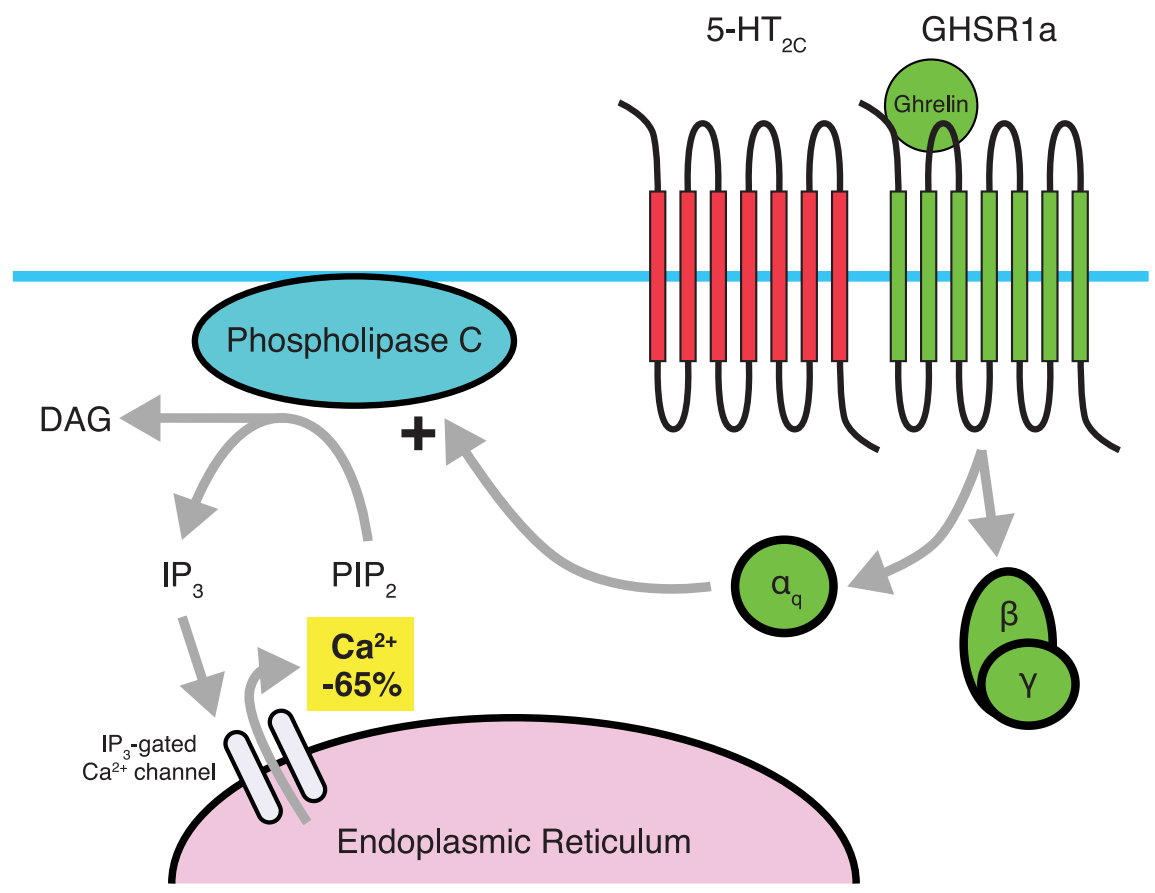

Figure 5 Dimerization between $5-\mathrm{HT}_{2 \mathrm{C}}$ and GHSR1a. When dimerized with $5-\mathrm{HT}_{2 \mathrm{C}}$. GHSR1a displays a $65 \%$ reduction in ghrelininduced $\mathrm{Ca}^{2+}$ accumulation, with this effect not requiring the presence of a $5-\mathrm{HT}_{2 \mathrm{C}}$ ligand. While changes in serotonergic signaling associated with the dimer through $5-\mathrm{HT}_{2 \mathrm{C}}$ have not yet been observed, cross-desensitization, cross-sensitization, and cointernalization do occur.

the GHSR1a inverse agonist SP-analog only results in a small, nonsignificant reduction in internalization (Schellekens et al., 2013). However, this mild reduction is enough to demonstrate a significant increase in cointernalization in response to $\left[\mathrm{Nle}^{4}, \mathrm{D}-\mathrm{Phe}^{7}\right]-\alpha-\mathrm{MSH}$ when compared to the SP-analog treatment (Schellekens et al., 2013). In contrast, treatment with $\left[\mathrm{Nle}^{4}, \mathrm{D}-\mathrm{Phe}^{7}\right]-\alpha-\mathrm{MSH}$ does not result in a significant increase in cointernalization when compared to controls (Schellekens et al., 2013).

Nevertheless, both Schellekens et al.'s (2013) and Rediger et al.'s (2009) studies demonstrate a significant loss of both ligand-independent and ligand-dependent GHSR1a-mediated $\mathrm{Ca}^{2+}$ accumulation when the GHSR1a is dimerized with the MC3R. These data suggest that GHSR1a signaling may be compromised in areas such as the arcuate nucleus, where high levels of both MC3R and GHSR1a expression are reported (Rediger et al., 2009). The conditions that lead to this dimerization, as well as the specific cell groups showing coexpression of both GHSR1a and MC3R, remain to be fully characterized and should be examined in detail. In particular, looking at the melanocortin system by way of examining which neurons show dimerization between MC3R and GHSR1a may add a new level of complexity in the mechanisms underlying the melanocortin feeding system.

\section{GHSR1a dimerization with $5-\mathrm{HT}_{2 \mathrm{C}}$ results in reduced GHSR1a signaling}

Recently, the $5-\mathrm{HT}_{2 \mathrm{C}}$ receptor has also been identified as a dimerization partner of GHSR1a (Fig. 5). Like the GHSR1a, the $5-\mathrm{HT}_{2 \mathrm{C}}$ serotonin receptor signals through a
$\mathrm{G} \alpha_{\mathrm{q}}$ pathway, leading to $\mathrm{Ca}^{2+}$ accumulation (Schellekens et al., 2013). Paradoxically, stimulation of the $5-\mathrm{HT}_{2 \mathrm{C}}$ receptor results in decreased food intake and adiposity, while mutations to the gene encoding for this receptor result in obesity (Sargent et al., 1997; Martin et al., 1998; Nonogaki et al., 1998; Somerville et al., 2007; Garfield and Heisler, 2009). One proposed mechanism of action is that stimulation of $5-\mathrm{HT}_{2 \mathrm{C}}$ receptors in pro-opiomelanocortin (POMC) neurons within the arcuate nucleus of the hypothalamus leads to increased release of $\alpha$-MSH (Garfield and Heisler, 2009).

Recently, Schellekens et al. (2013) examined the possibility of a $5-\mathrm{HT}_{2 \mathrm{C}}-\mathrm{GHSR} 1 \mathrm{a}$ heterodimer that explained the interaction between serotonin and ghrelin reported in the literature. This included, for instance, negative feedback from $5-\mathrm{HT}_{2 \mathrm{C}}$ receptor agonism onto ghrelin levels in overnight fasted mice (Nonogaki et al., 2006); the inhibition of serotonin release by ghrelin in rat hypothalamic synaptosomes (Brunetti et al., 2002); the effects of serotonin on reward-related behaviors (Higgins and Fletcher, 2003; Alex and Pehek, 2007); the ability of serotonin to block ghrelin's orexigenic effects (Currie et al., 2010); and some of the overlapping expression profiles of $5-\mathrm{HT}_{2 \mathrm{C}}$ and GHSR1a (Abramowski et al., 1995; Guan et al., 1997; Cowley et al., 2003; Zigman et al., 2006). This group demonstrated that dimerization occurs between $5-\mathrm{HT}_{2 \mathrm{C}}$ and GHSR1a. In particular, pretreatment with the GHSR1a inverse agonist SP-analog results in crosssensitization to the $5-\mathrm{HT}_{2 \mathrm{C}}$ response in cells coexpressing GHSR1a and 5- $\mathrm{HT}_{2 \mathrm{C}}$ (Schellekens et al., 2013). Typically, in cells expressing GHSR1a alone, pretreatment with SP- 
analog results in increased surface expression of GHSR1a and increased sensitivity. Additionally, cells expressing both receptors show a $65 \%$ attenuation of $\mathrm{Ca}^{2+}$ accumulation in response to ghrelin or the ghrelin agonist MK0677, with this attenuation being mostly restored by the $5-\mathrm{HT}_{2 \mathrm{C}}$ specific antagonist RS102221. Interestingly, beyond sensitivity and internalization effects, no immediate modification of $5-\mathrm{HT}_{2 \mathrm{C}}$ signaling occurs in any of these situations (Schellekens et al., 2013).

When exposed to ghrelin, an increase in $5-\mathrm{HT}_{2 \mathrm{C}^{-}}$ GHSR1a dimer cointernalization occurs (Schellekens et al., 2013). While exposure to the synthetic GHSR1a agonist MK-0677 results in an increase in internalization, this increase does not reach significance when compared to control, whereas it does reach significance compared to SP-analog (Schellekens et al., 2013). Schellekens et al. (2013) suggest that the lack of significance is likely due to the high levels of cointernalization under control conditions. Overall, it appears that GHSR1a dimerization with $5-\mathrm{HT}_{2 \mathrm{C}}$ reduces overall ghrelin signaling, and hence may reduce feeding behavior.

\section{Possible Dimerization with the Cannabinoid Receptor Type 1}

While dimerization between the endocannabinoid receptor CB1 and GHSR1a has not been examined directly, there is evidence suggesting that such dimerization may occur. It has been previously shown that both ghrelin (via GHSR1a) and the cannabinoids (via CB1) have orexigenic effects (Williams et al., 1998; Inui, 2001), with both increasing AMP-activated protein kinase (AMPK) activity in the hypothalamus and reducing it in the liver and adipose tissue (Kola et al., 2005). Interestingly, Kola and colleagues (2008) demonstrated that ghrelin's orexigenic and stimulating AMPK effects in the hypothalamus are lost in CB1 KO or mice treated with the CB1 antagonist Rimonabant. Patch-clamp electrophysiology of parvocellular neurons of the paraventricular nucleus also indicated that application of the CB1 antagonist AM251 eliminated ghrelin's electrophysiological effects (Kola et al., 2008). In addition to this, ghrelin increases endocannabinoids in the hypothalamus of wild-type but not CB1 KO mice (Kola et al., 2008). Conversely, administration of HU210 (a CB1 agonist) significantly stimulated hypothalamic AMPK activity and inhibited visceral fat and liver AMPK activity in wild-type mice, but these effects were lost in GHSR KO animals (Lim et al., 2013). Additionally, while no significance was found, a trend to an increase in food intake with intraperitoneal injection of HU210 was observed; this trend was not visible in GHSR KO mice (Lim et al., 2013).

These data provide preliminary evidence of the possible dimerization between CB1 and GHSR1a, as suggested by Lim et al. (2013). Despite this, one must also consider the possibility that this dependence is not due to dimerization. In one model suggested by Kola and Korbonits (2009), endocannabinoid synthesis is placed downstream of GHSR1a activation, with GHSR KO animals having no endocannabinoid-associated response to ghrelin administration. However, the bidirectional dependency between CB1 and GHSR1a presented in the study is suggestive of a receptor interaction. Nevertheless, it is possible that positive feedback between the two systems is required for ample $\mathrm{Ca}^{2+}$ accumulation to occur to induce increases in AMPK and affect feeding. In addition to ghrelin losing its feeding effect in $C B 1^{-1-}$ animals, neuropeptide $Y$ (NPY) has also been shown to lose its feeding effect in $\mathrm{CB}^{-1-}$ animals (Poncelet et al., 2003). In Kola's model, NPY signaling occurs downstream of both GHSR1a and CB1. Whether a possible positive feedback loop includes NPY as well is not known, but the system is no doubt more complicated than presented here.

\section{General treatment approaches}

As summarized in Figure 6, the dimer partners discussed in this review provide hints as to possible treatment targets for various disorders and conditions. In some cases, these treatments could involve the use of multiple drugs to provide a synergistic effect, amplifying the effect seen when only one drug is administered. In others, supplementing a treatment with an amplifying agent may have beneficial off-target effects beyond synergy. In such cases, not only do these treatments amplify neurotransmitter receptor signaling, but they may have other possible effects such as reduction in depression, neuroprotection, and stimulation of appetite-all effects that may relate to the effects on GHSR alone and not the dimer. The identification of GHSR heterodimers certainly opens the door for potential new treatments and treatment adjuvants that could improve a number of chronic psychiatric and metabolic conditions.

\section{Targeting the D1R-GHSR1a dimer for treatment of Parkinson's disease}

A standard treatment for Parkinson's disease typically involves the use of drugs that restore dopamine concentrations from the low levels caused by the loss of dopaminergic neurons in the substantia nigra (Mercuri and Bernardi, 2005). The coexpression of the ghrelin and D1 receptors in this area suggests that supplementing this treatment, or perhaps even replacing it, with a ghrelin mimetic may help amplify D1 signaling of the remaining dopaminergic activity. The addition of a ghrelin mimetic may also aid through other ghrelinrelated actions, including neuroprotection. Indeed, several studies have examined the beneficial effects of ghrelin in treatment for Parkinson's disease. In particular, ghrelin and its receptor have been shown to protect dopaminergic function from 1-methyl-4-phenyl1,2,3,6-tetrahydropyridine (MPTP)-induced degeneration in the substantia nigra pars compacta and the dorsal striatum (Andrews et al., 2009; Moon et al., 2009). Andrews and colleagues (2009) demonstrated that MPTP-induced dopaminergic dysfunction is amplified in GHSR KO animals, and selective re-expression of GHSR1a in catecholaminergic neurons of GHSR KO animals reduced this degeneration. These data suggest that ghrelin may aid in two ways: (1) by amplifying the remaining dopaminergic signaling through the D1R-GHSR1a dimer, and (2) by providing neuroprotective effects that may aid in slowing the progression of further dopaminer- 


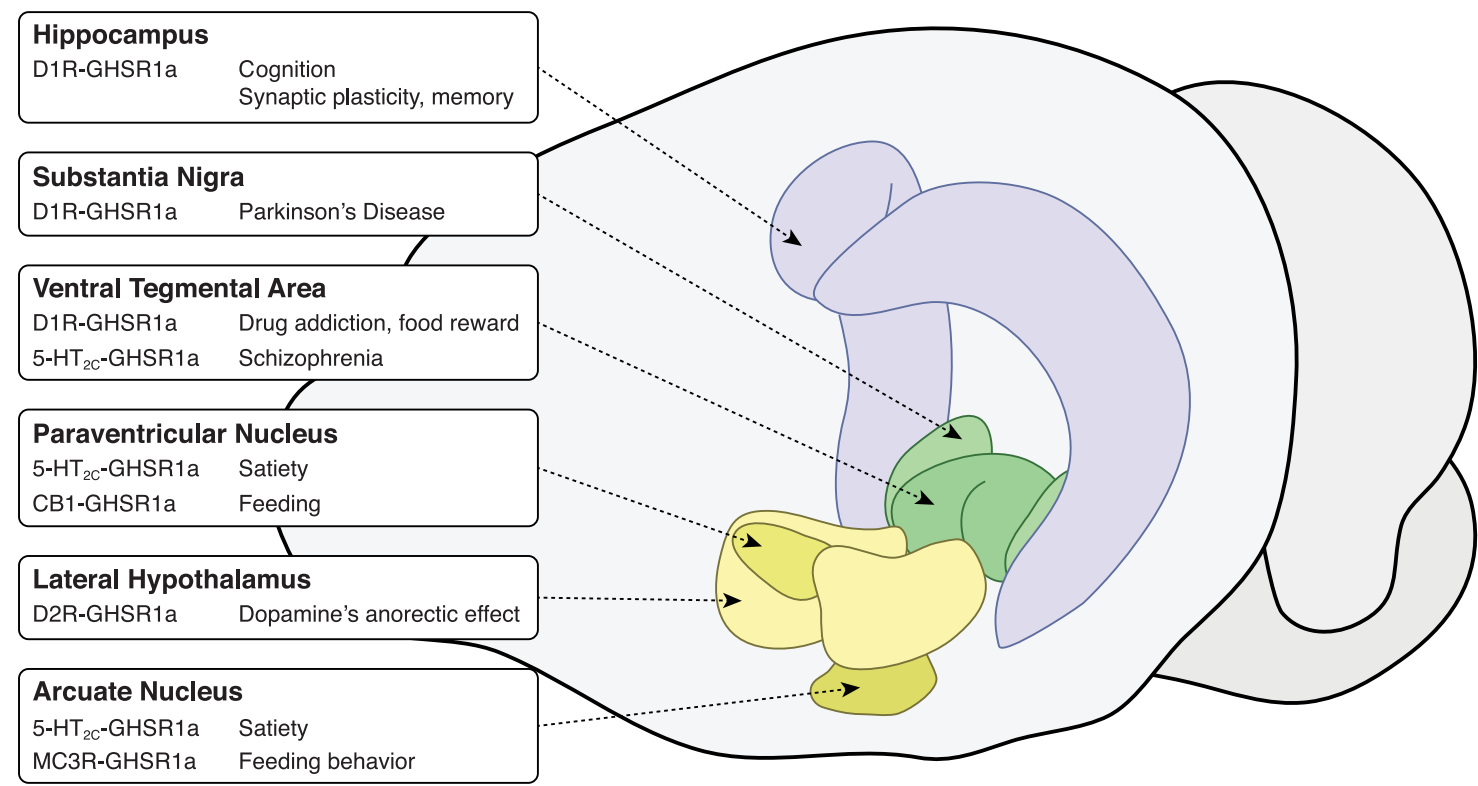

Figure 6 Selected areas of interest involving possible GHSR1a dimers along with postulated roles/treatments. Brain figure adapted from the Allen Mouse Brain Atlas (Lein et al., 2007).

gic degeneration, which may be the result of GHSR signaling alone.

\section{Treating drug addiction and preventing relapse with ghrelin antagonists}

There is now substantial evidence suggesting that GHSR located in the mesolimbic dopaminergic system is associated with the amplification of reward-seeking behaviors, including those associated with drugs of abuse (Abizaid, 2009; Dickson et al., 2011; Suchankova et al., 2013; Wellman et al., 2013; Leggio et al., 2014). Given the described D1R-GHSR1a dimer, one could propose that GHSR antagonism reduces the reinforcing effects of drugs of abuse like alcohol, nicotine, and cocaine by reducing D1 receptor signaling produced by the D1RGHSR1a dimer. Enhanced D1 receptor signaling would also explain why addicts are more prone to relapse when stressed or hungry, both conditions that augment ghrelin secretion and sensitivity (Carroll, 1985; Brown et al., 1995; Shalev et al., 2000; Shalev et al., 2001; Goeders, 2003; Sinha et al., 2006). In these cases, increases in acylated ghrelin levels, or increased GHSR1a expression, may enhance the sensitivity of the mesolimbic dopaminergic system where GHSR1a and D1R are coexpressed. Relapse may then be more a function of dopaminergic sensitivity, as mediated by the ghrelin receptor. If such hypotheses are correct, administration of a GHSR1a antagonist or a GOAT inhibitor may aid in drug addiction as well as in dieting. Pharmacological blockade of the GHSR1a or genetic ablation of this gene would result in decreased reward seeking behaviors. Indeed this seems to be the case, as GHSR1a KO mice display reduced foodanticipatory activity (Blum et al., 2009; Davis et al., 2011) and reduced food reward as measured by conditioned place preference (Zigman et al., 2005; Egecioglu et al., 2010; Perello et al., 2010; Chuang et al., 2011). Further- more, locomotor responses to cocaine and alcohol selfadministration are attenuated in GHSR1a- and ghrelindeficient mice and rats (Jerlhag et al., 2010; Abizaid et al., 2011; Clifford et al., 2012). More research is needed, however, to specifically target the D1R-GHSR dimer and pinpoint its role in reward mechanisms, but it is clear that this would represent a fresh target for the treatment of addictions and the prevention of relapse.

\section{GHSR1a heterodimers as a target for the treatment of schizophrenia, obesity, and addiction}

5- $H T_{2 C}-$ GHSR1a dimer

In general, patients suffering from schizophrenia are treated with typical or atypical antipsychotic drugs. Typical antipsychotics generally block D2 dopamine receptor signaling, whereas atypical antipsychotics block both D2like receptors and serotonin $5-\mathrm{HT}_{2 \mathrm{~A}}$ receptors. Both classes of antipsychotic medications have a number of side effects that include motor dysfunction (dyskinesia), obesity, and cardiovascular disease, as well as some endocrine abnormalities (for review, see Young et al., 2015). Interestingly, $5-\mathrm{HT}_{2 \mathrm{C}}$ receptor modulators, and in particular $5-\mathrm{HT}_{2 \mathrm{C}}$ agonists, have been identified as potential antipsychotic medications with fewer side effects (for review, see Rosenzweig-Lipson et al., 2012). Indeed $5-\mathrm{HT}_{2 \mathrm{C}}$ agonists appear to regulate DA neurotransmission by decreasing DA cell activity in the VTA, a region also rich in GHSR1a expression (Di Giovanni et al., 2000). Additionally, treatment with $5-\mathrm{HT}_{2 \mathrm{C}}$ antagonists enhances ghrelin-induced food intake, whereas treatment with lorcaserin, a $5-\mathrm{HT}_{2 \mathrm{C}}$ agonist, decreases ghrelin-induced food intake (Schellekens et al., 2015). These behavioral effects may be mediated by internalization or changes in sensitivity of the $5-\mathrm{HT}_{2 \mathrm{C}}-\mathrm{GHSR} 1 \mathrm{a}$ receptor dimer.

Interestingly, pretreatment with the GHSR inverse agonist SP-analog enhances $5-\mathrm{HT}_{2 \mathrm{C}}$ intracellular receptor 
signaling, supporting the notion that inverse agonists of the GHSR (and perhaps antagonists) may augment the effectiveness of $5-\mathrm{HT}_{2 \mathrm{C}}$ in the treatment of schizophrenia. These effects, however, are likely sensitive to the timing of exposure of the dimer to the various ligands. Furthermore, given that the effects of $5-\mathrm{HT}_{2 \mathrm{C}}$ agonists also include weight loss and a reduction in reward-seeking behaviors, the use of compounds that enhance $5-\mathrm{HT}_{2 \mathrm{C}}$ signaling would also be clinically relevant for the treatment of obesity or to prevent relapse to drug abuse. This certainly warrants further exploration.

\section{D2R-GHSR1a dimer}

When Kern et al. (2012) administered the D2R agonist cabergoline following pretreatment with the GHSR1a neutral antagonist JMV2959, cabergoline's anorexigenic effects were lost. Based on this result, the authors argue that antagonism of the ghrelin system may exacerbate rather than ameliorate obesity. Complicating the matter, administration of ghrelin still leads to crossdesensitization of dopamine-induced $\mathrm{Ca}^{2+}$ mobilization, and while ghrelin antagonism also reduces this mobilization, it is possible that concurrent cross-sensitization may also occur, which may possibly carry beyond the timeframe of bioavailability of such an antagonist. The balance between such effects, particularly over a prolonged timeframe, including effects at other GHSR1a monomers or GHSR1a heterodimers with other receptor types, must be taken into consideration.

\section{MC3R-GHSR1a dimer}

Being a system involved in satiety, the melanocortin system is a promising target for treatment of obesity and diabetes. While the melanocortin 4 receptor (MC4R) has often been the target for obesity treatment, to the best of our knowledge no dimerization between GHSR1a and MC4R has been identified. As was done in the study of D2R's anorexigenic effects, the role of the GHSR1aMC3R dimer may be teased apart by examining GHSR $K O$ animals and MC3R agonists/antagonists. In addition to its role in feeding, evidence suggests that activation of MC3R may aid in insulin sensitivity and glucose control. While MC4R KO mice generally demonstrate a more severe diabetic phenotype, male MC3R KO mice nevertheless do display mild impairments in insulin sensitivity and glucose control, along with increased adiposity (Butler et al., 2000; Sutton et al., 2006). Administration of a melanocortin agonist to mice lacking MC4R but not MC3R improves hyperinsulinemia and homeostasis model assessment of insulin resistance (HOMA-IR) scores (Kumar et al., 2009). Furthermore, the coexpression of MC3R and GHSR1a in the hypothalamic arcuate nucleus suggests that this dimer may play a role in arcuatemediated feeding behavior (Roselli-Rehfuss et al., 1993; Howard et al., 1996; Guan et al., 1997; Kistler et al., 1998; Jégou et al., 2000; Archer et al., 2004; Rediger et al., 2009).

Within the GHSR1a-MC3R dimer, the GHSR1a inverse agonist SP-analog eliminates amplification of MC3R signaling (Rediger et al., 2011), an effect likely due to the dependence on GHSR1a constitutive activity. While SP- analog has been shown to reduce weight gain, and hence likely aid in treatment of diabetes and obesity (Asakawa et al., 2003), when considering the dimer alone this attenuation may not be beneficial. GHSR1a neutral antagonists, however, do not eliminate basal activity, although the effects of such compounds on GHSR1a-MC3R have not been examined. Although there is no reason to believe that a neutral antagonist would directly affect MC3R signaling, the possibility remains that such an antagonist may lead to cross-sensitization or reduced internalization of the dimer, in effect amplifying MC3R signaling further through increased surface expression or sensitization.

\section{CB1-GHSR1a dimer}

While dimerization between the CB1 and GHSR1a receptors has not been fully confirmed, there is evidence suggesting that feeding responses to cannabinoids require intact GHSR1a receptors, and feeding responses to ghrelin require $\mathrm{CB} 1$ receptors. While one would suspect that coadministration of rimonabant, a selective CB1 antagonist, with a GHSR1a antagonist or inverse agonist may help to decrease appetite, or may reduce body weight with less side effects due to reduced dosage (RinaldiCarmona et al., 1994; Després et al., 2005), our current understanding of this potential dimer is too limited to allow us to speculate how such poly-drug treatment would affect signaling at the dimer. Alternatively, a combination of CB1 and GHSR1a agonists could be used to increase appetite and decrease nausea, for instance, in patients undergoing chemotherapy. Understanding the intracellular mechanisms underlying the interaction between these receptors may help improve CB1- or GHSR1a-based treatments to combat obesity.

\section{Conclusion}

One of the big questions surrounding the ghrelinergic system has been the role of the ghrelin receptor in the brain. Demonstrating the presence of the ghrelin peptide centrally has remained difficult, and hence no definite ligand for GHSR1a has been identified in many areas of the brain. Following the identification of GHSR1a's constitutive activity, investigators quickly started identifying dimerization partners of GHSR1a that occur under normal biological conditions with considerable evidence of activity resulting from the dimerized complexes. Thus, even in the absence of GHSR1a's natural ligand, GHSR1a appears to have significant physiological effects via these protein-protein complexes.

Understanding how these dimers work, including how the signaling of each protomer is modified and how they affect different pathways and systems, is an area that should be enthusiastically studied by those interested in the development of novel pharmacological treatments. Being a receptor involved in many systems, including reward, feeding, and memory, GHSR1a represents an important target for the treatment of psychiatric and metabolic disorders. Due to its broad distribution, however, a wide range of side effects would be expected by targeting this receptor. While the technology does not yet exist, by narrowing the pharmacological target of drugs to specific dimers involving GHSR1a, it may be possible to signifi- 
cantly reduce side effects while targeting with more precision the culprits involved in the disorder being treated. Regardless of our ability to develop such drugs, by increasing our understanding of the changes induced by dimerization, one would hope that our ability to understand and treat disorders, such as through poly-drug treatments, will improve. Identification of the dimer partners presented here, which include $5-\mathrm{HT}_{2 \mathrm{C}}, \mathrm{MC} 3 \mathrm{R}, \mathrm{D} 1 \mathrm{R}$, $\mathrm{D} 2 \mathrm{R}$, and $\mathrm{CB} 1$, represents only the beginning of our knowledge regarding dimerization involving GHSR1a. We can say with confidence that many more dimer partners will be identified within the near future.

\section{References}

Abizaid A (2009) Ghrelin and dopamine: new insights on the peripheral regulation of appetite. J Neuroendocrinol 21:787-793. CrossRef Medline

Abizaid A, Horvath TL (2008) Brain circuits regulating energy homeostasis. Regul Pept 149:3-10. CrossRef Medline

Abizaid A, Liu ZW, Andrews ZB, Shanabrough M, Borok E, Elsworth JD, Roth RH, Sleeman MW, Picciotto MR, Tschöp MH, Gao XB, Horvath TL (2006) Ghrelin modulates the activity and synaptic input organization of midbrain dopamine neurons while promoting appetite. J Clin Invest 116:3229-3239. CrossRef

Abizaid A, Mineur YS, Roth RH, Elsworth JD, Sleeman MW, Picciotto MR, Horvath TL (2011) Reduced locomotor responses to cocaine in ghrelin-deficient mice. Neuroscience 192:500-506. CrossRef Medline

Abramowski D, Rigo M, Duc D, Hoyer D, Staufenbiel M (1995) Localization of the 5-hydroxytryptamine2C receptor protein in human and rat brain using specific antisera. Neuropharmacology 34:1635-1645. Medline

Alex KD, Pehek EA (2007) Pharmacologic mechanisms of serotonergic regulation of dopamine neurotransmission. Pharmacol Ther 113:296-320. CrossRef Medline

Andrews ZB, Erion D, Beiler R, Liu ZW, Abizaid A, Zigman J, Elsworth JD, Savitt JM, DiMarchi R, Tschöp M, Roth RH, Gao XB, Horvath TL (2009) Ghrelin promotes and protects nigrostriatal dopamine function via a UCP2-dependent mitochondrial mechanism. J Neurosci 29:14057-14065. CrossRef Medline

Archer ZA, Dieguez C, Mitchell SE, Nogueiras R, Rayner DV, Tovar S, Williams LM (2004) Regulation of growth hormone secretagogue receptor gene expression in the arcuate nuclei of the rat by leptin and ghrelin. Diabetes 53:2552-2558. CrossRef

Asakawa A, Inui A, Kaga T, Katsuura G, Fujimiya M, Fujino MA, Kasuga M (2003) Antagonism of ghrelin receptor reduces food intake and body weight gain in mice. Gut 52:947-952. Medline

Banks WA, Tschöp M, Robinson SM, Heiman ML (2002) Extent and direction of ghrelin transport across the blood-brain barrier is determined by its unique primary structure. J Pharmacol Exp Ther 302:822-827. CrossRef Medline

Blum ID, Patterson Z, Khazall R, Lamont EW, Sleeman MW, Horvath TL, Abizaid A (2009) Reduced anticipatory locomotor responses to scheduled meals in ghrelin receptor deficient mice. Neuroscience 164:351-359. CrossRef Medline

Breit A, Wolff K, Kalwa H, Jarry H, Büch T, Gudermann T (2006) The natural inverse agonist agouti-related protein induces arrestinmediated endocytosis of melanocortin-3 and -4 receptors. J Biol Chem 281:37447-37456. CrossRef Medline

Brown SA, Vik PW, Patterson TL, Grant I, Schuckit MA (1995) Stress, vulnerability and adult alcohol relapse. J Stud Alcohol 56:538-545. Medline

Brunetti L, Recinella L, Orlando G, Michelotto B, Di Nisio C, Vacca M (2002) Effects of ghrelin and amylin on dopamine, norepinephrine and serotonin release in the hypothalamus. Eur J Pharmacol 454: 189-192. Medline
Butler AA, Kesterson RA, Khong K, Cullen MJ, Pelleymounter MA, Dekoning J, Baetscher M, Cone RD (2000) A unique metabolic syndrome causes obesity in the melanocortin-3 receptor-deficient mouse. Endocrinology 141:3518-3521. CrossRef Medline

Cabral A, Fernandez G, Perello M (2013) Analysis of brain nuclei accessible to ghrelin present in the cerebrospinal fluid. Neuroscience 253:406-415. CrossRef Medline

Camiña JP, Lodeiro M, Ischenko O, Martini AC, Casanueva FF (2007) Stimulation by ghrelin of p42/p44 mitogen-activated protein kinase through the GHS-R1a receptor: role of G-proteins and $\beta$-arrestins. J Cell Physiol 213:187-200. CrossRef Medline

Carroll ME (1985) The role of food deprivation in the maintenance and reinstatement of cocaine-seeking behavior in rats. Drug Alcohol Depend 16:95-109. Medline

Centonze D, Picconi B, Gubellini P, Bernardi G, Calabresi P (2001) Dopaminergic control of synaptic plasticity in the dorsal striatum. Eur J Neurosci 13:1071-1077. Medline

Centonze D, Grande C, Saulle E, Martín AB, Gubellini P, Pavón N, Pisani A, Bernardi G, Moratalla R, Calabresi P (2003) Distinct roles of D1 and D5 dopamine receptors in motor activity and striatal synaptic plasticity. J Neurosci 23:8506-8512. Medline

Chen AS, Marsh DJ, Trumbauer ME, Frazier EG, Guan XM, Yu H, Rosenblum Cl, Vongs A, Feng Y, Cao L, Metzger JM, Strack AM, Camacho RE, Mellin TN, Nunes CN, Min W, Fisher J, Gopal-Truter S, Maclntyre DE, Chen HY, Van der Ploeg LH (2000) Inactivation of the mouse melanocortin-3 receptor results in increased fat mass and reduced lean body mass. Nat Genet 26:97-102. CrossRef Medline

Chen YW, Morganstern I, Barson JR, Hoebel BG, Leibowitz SF (2014) Differential role of D1 and D2 receptors in the perifornical lateral hypothalamus in controlling ethanol drinking and food intake: possible interaction with local orexin neurons. Alcohol Clin Exp Res 38:777-786. CrossRef

Chuang JC, Perello M, Sakata I, Osborne-Lawrence S, Savitt JM, Lutter M, Zigman JM (2011) Ghrelin mediates stress-induced foodreward behavior in mice. J Clin Invest 121:2684-2692. CrossRef Medline

Clifford PS, Rodriguez J, Schul D, Hughes S, Kniffin T, Hart N, Eitan S, Brunel L, Fehrentz JA, Martinez J, Wellman PJ (2012) Attenuation of cocaine-induced locomotor sensitization in rats sustaining genetic or pharmacologic antagonism of ghrelin receptors. Addict Biol 17:956-963. CrossRef Medline

Cowley MA, Pronchuk N, Fan W, Dinulescu DM, Colmers WF, Cone RD (1999) Integration of NPY, AGRP, and melanocortin signals in the hypothalamic paraventricular nucleus: evidence of a cellular basis for the adipostat. Neuron 24:155-163. Medline

Cowley MA, Smith RG, Diano S, Tschöp M, Pronchuk N, Grove KL, Strasburger CJ, Bidlingmaier M, Esterman M, Heiman ML, GarciaSegura LM, Nillni EA, Mendez P, Low MJ, Sotonyi P, Friedman JM, Liu H, Pinto S, Colmers WF, Cone RD, Horvath TL (2003) The distribution and mechanism of action of ghrelin in the CNS demonstrates a novel hypothalamic circuit regulating energy homeostasis. Neuron 37:649-661. Medline

Currie PJ, John CS, Nicholson ML, Chapman CD, Loera KE (2010) Hypothalamic paraventricular 5-hydroxytryptamine inhibits the effects of ghrelin on eating and energy substrate utilization. Pharmacol Biochem Behav 97:152-155. CrossRef

Cvejic S, Devi LA (1997) Dimerization of the $\delta$ opioid receptor: implication for a role in receptor internalization. J Biol Chem 272: 26959-26964. Medline

Damian M, Marie J, Leyris JP, Fehrentz JA, Verdie P, Martinez J, Baneres JL, Mary S (2011) High constitutive activity is an intrinsic feature of the ghrelin receptor protein. J Biol Chem 287:36303641.

Davis JF, Choi DL, Clegg DJ, Benoit SC (2011) Signaling through the ghrelin receptor modulates hippocampal function and meal anticipation in mice. Physiol Behav 103:39-43. CrossRef Medline

Després JP, Golay A, Sjöström L (2005) Effects of rimonabant on metabolic risk factors in overweight patients with dyslipidemia. $\mathrm{N}$ Engl J Med 353:2121-2134. CrossRef Medline 
Dickson SL, Egecioglu E, Landgren S, Skibicka KP, Engel JA, Jerlhag $E$ (2011) The role of the central ghrelin system in reward from food and chemical drugs. Mol Cell Endocrinol 340:80-87. CrossRef Medline

Di Giovanni G, Di Matteo V, Di Mascio M, Esposito E (2000) Preferential modulation of mesolimbic vs. nigrostriatal dopaminergic function by serotonin2C/2B receptor agonists: a combined in vivo electrophysiological and microdialysis study. Synapse 35:53-61. CrossRef

Double KL, Crocker AD (1995) Dopamine receptors in the substantia nigra are involved in the regulation of muscle tone. Proc Natl Acad Sci U S A 92:1669-1673. Medline

Egecioglu E, Jerlhag E, Salomé N, Skibicka KP, Haage D, Bohlooly-Y M, Andersson D, Bjursell M, Perrissoud D, Engel JA, Dickson SL (2010) Ghrelin increases intake of rewarding food in rodents. Addict Biol 15:304-311. CrossRef Medline

Esen-Danaci A, Sarandöl A, Taneli F, Yurtsever F, Özlen N (2008) Effects of second generation antipsychotics on leptin and ghrelin. Prog Neuropsychopharmacol Biol Psychiatry 32:1434-1438. CrossRef Medline

Fan W, Boston BA, Kesterson RA, Hruby VJ, Cone RD (1997) Role of melanocortinergic neurons in feeding and the agouti obesity syndrome. Nature 385:165-168. CrossRef Medline

Fredholm BB, Hökfelt T, Milligan G (2007) G-protein-coupled receptors: an update. Acta Physiol 190:3-7. CrossRef Medline

Garfield AS, Heisler LK (2009) Pharmacological targeting of the serotonergic system for the treatment of obesity. J Physiol 587: 49-60. CrossRef Medline

Gnanapavan S, Kola B, Bustin SA, Morris DG, McGee P, Fairclough P, Bhattacharya S, Carpenter R, Grossman AB, Korbonits M (2002) The tissue distribution of the mRNA of ghrelin and subtypes of its receptor, GHS-R, in humans. J Clin Endocrinol Metab 87:2988. CrossRef Medline

Goeders NE (2003) The impact of stress on addiction. Eur Neuropsychopharmacol 13:435-441. Medline

Granado N, Ortiz O, Suárez LM, Martín ED, Ceña V, Solís JM, Moratalla R (2008) D1 but not D5 dopamine receptors are critical for LTP, spatial learning, and LTP-induced arc and zif268 expression in the hippocampus. Cereb Cortex 18:1-12. CrossRef Medline

Guan XM, Yu H, Palyha OC, McKee KK, Feighner SD, Sirinathsinghji DJ, Smith RG, Van der Ploeg LH, Howard AD (1997) Distribution of mRNA encoding the growth hormone secretagogue receptor in brain and peripheral tissues. Brain Res Mol Brain Res 48:23-29. Medline

Gutierrez JA, Solenberg PJ, Perkins DR, Willency JA, Knierman MD, Jin Z, Witcher DR, Luo S, Onyia JE, Hale JE (2008) Ghrelin octanoylation mediated by an orphan lipid transferase. Proc Natl Acad Sci U S A 105:6320-6325. CrossRef Medline

Hebert TE, Moffett S, Morello J-P, Loisel TP, Bichet DG, Barret C, Bouvier M (1996) A peptide derived from a $\beta 2$-adrenergic receptor transmembrane domain inhibits both receptor dimerization and activation. J Biol Chem 271:16384-16392. Medline

Higgins GA, Fletcher PJ (2003) Serotonin and drug reward: focus on 5-HT2C receptors. Eur J Pharmacol 480:151-162. Medline

Holst B, Cygankiewicz A, Jensen TH, Ankersen M, Schwartz TW (2003) High constitutive signaling of the ghrelin receptor-identification of a potent inverse agonist. Mol Endocrinol 17:2201-2210. CrossRef Medline

Holst B, Holliday ND, Bach A, Elling CE, Cox HM, Schwartz TW (2004) Common structural basis for constitutive activity of the ghrelin receptor family. J Biol Chem 279:53806-53817. CrossRef Medline

Hosoda H, Kojima M, Matsuo H, Kangawa K (2000) Ghrelin and des-acyl ghrelin: two major forms of rat ghrelin peptide in gastrointestinal tissue. Biochem Biophys Res Commun 279:909-913. CrossRef Medline

Howard AD, Feighner SD, Cully DF, Arena JP, Liberator PA, Rosenblum Cl, Hamelin M, Hreniuk DL, Palyha OC, Anderson J, Paress PS, Diaz C, Chou M, Liu KK, McKee KK, Pong SS, Chaung LY, Elbrecht A, Dashkevicz M, Heavens R, Rigby M, et al. (1996) A receptor in pituitary and hypothalamus that functions in growth hormone release. Science 273:974-977. Medline

Ikemoto S (2003) Involvement of the olfactory tubercle in cocaine reward: intracranial self-administration studies. J Neurosci 23: 9305-9311. Medline

Ikemoto S, Glazier BS, Murphy JM, McBride WJ (1997) Role of Dopamine D1 and D2 receptors in the nucleus accumbens in mediating reward. J Neurosci 17:8580-8587. Medline

Inui A (2001) Ghrelin: an orexigenic and somatotrophic signal from the stomach. Nat Rev Neurosci 2:551-560. CrossRef Medline

Jégou S, Boutelet I, Vaudry H (2000) Melanocortin-3 receptor mRNA expression in pro-opiomelanocortin neurones of the rat arcuate nucleus. J Neuroendocrinol 12:501-505. Medline

Jerlhag E, Egecioglu E, Dickson S, Engel J (2010) Ghrelin receptor antagonism attenuates cocaine- and amphetamine-induced locomotor stimulation, accumbal dopamine release, and conditioned place preference. Psychopharmacology (Berl) 211:415-422. CrossRef Medline

Jiang H, Betancourt L, Smith RG (2006) Ghrelin amplifies dopamine signaling by cross talk involving formation of growth hormone secretagogue receptor/dopamine receptor subtype 1 heterodimers. Mol Endocrinol 20:1772-1785. CrossRef Medline

Jones KA, Borowsky B, Tamm JA, Craig DA, Durkin MM, Dai M, Yao W-J, Johnson M, Gunwaldsen C, Huang L-Y, Tang C, Shen Q, Salon JA, Morse K, Laz T, Smith KE, Nagarathnam D, Noble SA, Branchek TA, Gerald C (1998) GABA(B) receptors function as a heteromeric assembly of the subunits $\mathrm{GABA}(\mathrm{B}) \mathrm{R} 1$ and GABA(B)R2. Nature 396:674-679. CrossRef Medline

Kammerer RA, Frank S, Schulthess T, Landwehr R, Lustig A, Engel J (1999) Heterodimerization of a functional GABAB receptor is mediated by parallel coiled-coil $\alpha$-helices. Biochemistry 38:1326313269. Medline

Kaupmann K, Malitschek B, Schuler V, Heid J, Froestl W, Beck P, Mosbacher J, Bischoff S, Kulik A, Shigemoto R, Karschin A, Bettler B (1998) GABA(B)-receptor subtypes assemble into functional heteromeric complexes. Nature 396:683-687. CrossRef Medline

Kern A, Albarran-Zeckler R, Walsh HE, Smith RG (2012) Apo-ghrelin receptor forms heteromers with DRD2 in hypothalamic neurons and is essential for anorexigenic effects of DRD2 agonism. Neuron 73:317-332. CrossRef Medline

Kistler H, Lauber, Lichtensteiger (1998) Different developmental patterns of melanocortin MC3 and MC4 receptor mRNA: predominance of Mc4 in fetal rat nervous system. J Neuroendocrinol 10:133-146. Medline

Klingenberg M (1981) Membrane protein oligomeric structure and transport function. Nature 290:449-454. Medline

Kojima M, Hosoda H, Date Y, Nakazato M, Matsuo H, Kangawa K (1999) Ghrelin is a growth-hormone-releasing acylated peptide from stomach. Nature 402:656-660. CrossRef Medline

Kola B, Korbonits M (2009) Shedding light on the intricate puzzle of ghrelin's effects on appetite regulation. J Endocrinol 202:191-198. CrossRef Medline

Kola B, Farkas I, Christ-Crain M, Wittmann G, Lolli F, Amin F, Harvey-White J, Liposits Z, Kunos G, Grossman AB, Fekete C, Korbonits M (2008) The orexigenic effect of ghrelin is mediated through central activation of the endogenous cannabinoid system. PLoS One 3:e1797. CrossRef

Kola B, Hubina E, Tucci SA, Kirkham TC, Garcia EA, Mitchell SE, Williams LM, Hawley SA, Hardie DG, Grossman AB, Korbonits M (2005) Cannabinoids and ghrelin have both central and peripheral metabolic and cardiac effects via AMP-activated Protein kinase. J Biol Chem 280:25196-25201. CrossRef Medline

Kumar KG, Sutton GM, Dong JZ, Roubert P, Plas P, Halem HA, Culler MD, Yang H, Dixit VD, Butler AA (2009) Analysis of the therapeutic functions of novel melanocortin receptor agonists in MC3R- and MC4R-deficient C57BL/6J mice. Peptides 30:18921900. CrossRef Medline

Kuner R, Köhr G, Grünewald S, Eisenhardt G, Bach A, Kornau HC (1999) Role of heteromer formation in GABAB receptor function. Science 283:74-77. Medline 
Kurumiya S, Nakajima S (1988) Dopamine D1 receptors in the nucleus accumbens: involvement in the reinforcing effect of tegmental stimulation. Brain Res 448:1-6. Medline

Leggio L, Zywiak WH, Fricchione SR, Edwards SM, de la Monte SM, Swift RM, Kenna GA (2014) Intravenous ghrelin administration increases alcohol craving in alcohol-dependent heavy drinkers: a preliminary investigation. Biol Psychiatry 76:734-741. CrossRef Medline

Lein ES, Hawrylycz MJ, Ao N, Ayres M, Bensinger A, Bernard A, Boe AF, Boguski MS, Brockway KS, Byrnes EJ, Chen L, Chen L, Chen TM, Chin MC, Chong J, Crook BE, Czaplinska A, Dang CN, Datta S, Dee NR, et al. (2007) Genome-wide atlas of gene expression in the adult mouse brain. Nature 445:168-176. CrossRef Medline

Lim CT, Kola B, Feltrin D, Perez-Tilve D, Tschöp MH, Grossman AB, Korbonits M (2013) Ghrelin and cannabinoids require the ghrelin receptor to affect cellular energy metabolism. Mol Cell Endocrinol 365:303-308. CrossRef Medline

Lutter M, Sakata I, Osborne-Lawrence S, Rovinsky SA, Anderson JG, Jung S, Birnbaum S, Yanagisawa M, Elmquist JK, Nestler EJ, Zigman JM (2008) The orexigenic hormone ghrelin defends against depressive symptoms of chronic stress. Nat Neurosci 11:752-753. CrossRef Medline

Margeta-Mitrovic M, Jan YN, Jan LY (2000) A trafficking checkpoint controls GABA(B) receptor heterodimerization. Neuron 27:97-106. Medline

Martin JR, Bös M, Jenck F, Moreau J-L, Mutel V, Sleight AJ, Wichmann J, Andrews JS, Berendsen HHG, Broekkamp CLE, Ruigt GSF, Köhler C, van Delft AM (1998) 5-HT2C receptor agonists: pharmacological characteristics and therapeutic potential. J Pharmacol Exp Ther 286:913-924. Medline

Matthies H, Becker A, Krug M (1997) Dopamine D1-deficient mutant mice do not express the late phase of hippocampal long-term potentiation. Neuroreport 8:3533. Medline

Meador-Woodruff JH, Mansour A, Bunzow JR, Van Tol HH, Watson SJ, Civelli O (1989) Distribution of D2 dopamine receptor mRNA in rat brain. Proc Natl Acad Sci U S A 86:7625-7628. Medline

Mercuri NB, Bernardi G (2005) The magic of I-dopa: why is it the gold standard Parkinson's disease therapy? Trends Pharmacol Sci 26: 341-344. CrossRef Medline

Missale C, Nash SR, Robinson SW, Jaber M, Caron MG (1998) Dopamine receptors: from structure to function. Physiol Rev 78: 189-225.

Mitchell V, Bouret S, Beauvillain J-C, Schilling A, Perret M, Kordon C, Epelbaum J (2001) Comparative distribution of mRNA encoding the growth hormone secretagogue-receptor (GHS-R) in Microcebus murinus (Primate, Lemurian) and rat forebrain and pituitary. $J$ Comp Neurol 429:469-489. Medline

Moon M, Kim H, Hwang L, Seo J-H, Kim S, Hwang S, Kim S, Lee D, Chung H, Oh M, Lee KT, Park S (2009) Neuroprotective effect of ghrelin in the 1-methyl-4-phenyl-1,2,3,6-tetrahydropyridine mouse model of Parkinson's disease by blocking microglial activation. Neurotox Res 15:332-347. CrossRef Medline

Nakajima S (1989) Subtypes of dopamine receptors involved in the mechanism of reinforcement. Neurosci Biobehav Rev 13:123-128. Medline

Nakajima S, McKenzie GM (1986) Reduction of the rewarding effect of brain stimulation by a blockade of dopamine D1 receptor with $\mathrm{SCH}$ 23390. Pharmacol Biochem Behav 24:919-923. Medline

Neve KA, Seamans JK, Trantham-Davidson H (2004) Dopamine receptor signaling. J Recept Signal Transduct Res 24:165-205. Medline

Nonogaki K, Strack AM, Dallman MF, Tecott LH (1998) Leptinindependent hyperphagia and type 2 diabetes in mice with a mutated serotonin 5-HT2C receptor gene. Nat Med 4:1152-1156. CrossRef Medline

Nonogaki K, Ohashi-Nozue K, Oka Y (2006) A negative feedback system between brain serotonin systems and plasma active ghrelin levels in mice. Biochem Biophys Res Commun 341:703-707. CrossRef Medline
Otmakhova NA, Lisman JE (1996) D1/D5 dopamine receptor activation increases the magnitude of early long-term potentiation at CA1 hippocampal synapses. J Neurosci 16:7478-7486. Medline

Pantel J, Legendre M, Cabrol S, Hilal L, Hajaji Y, Morisset S, Nivot S, Vie-Luton MP, Grouselle D, de Kerdanet M, Kadiri A, Epelbaum J, Le Bouc Y, Amselem S (2006) Loss of constitutive activity of the growth hormone secretagogue receptor in familial short stature. J Clin Invest 116:760-768. CrossRef

Park PS, Filipek S, Wells JW, Palczewski K (2004) Oligomerization of $G$ protein-coupled receptors: past, present, and future. Biochemistry 43:15643-15656. CrossRef Medline

Patterson ZR, Ducharme R, Anisman H, Abizaid A (2010) Altered metabolic and neurochemical responses to chronic unpredictable stressors in ghrelin receptor-deficient mice. Eur J Neurosci 32: 632-639. CrossRef Medline

Perello M, Sakata I, Birnbaum S, Chuang JC, Osborne-Lawrence S, Rovinsky SA, Woloszyn J, Yanagisawa M, Lutter M, Zigman JM (2010) Ghrelin increases the rewarding value of high-fat diet in an orexin-dependent manner. Biol Psychiatry 67:880-886. CrossRef Medline

Pin JP, Neubig R, Bouvier M, Devi L, Filizola M, Javitch JA, Lohse MJ, Milligan G, Palczewski K, Parmentier M, Spedding M (2007) International union of basic and clinical pharmacology. LXVII. Recommendations for the recognition and nomenclature of $G$ proteincoupled receptor heteromultimers. Pharmacol Rev 59:5-13. CrossRef Medline

Poncelet M, Maruani J, Calassi R, Soubrié P (2003) Overeating, alcohol and sucrose consumption decrease in CB1 receptor deleted mice. Neurosci Lett 343:216-218. Medline

Rediger A, Tarnow P, Bickenbach A, Schaefer M, Krude H, Grüters A, Biebermann H (2009) Heterodimerization of hypothalamic G-protein-coupled receptors involved in weight regulation. Obes Facts 2:80-86. CrossRef Medline

Rediger A, Piechowski CL, Yi C-X, Tarnow P, Strotmann R, Grüters A, Krude H, Schöneberg T, Tschöp MH, Kleinau G, Biebermann H (2011) Mutually opposite signal modulation by hypothalamic heterodimerization of ghrelin and melanocortin-3 receptors. J Biol Chem 286:39623-39631. CrossRef Medline

Rinaldi-Carmona $M$, Barth $F$, Héaulme $M$, Shire $D$, Calandra $B$, Congy C, Martinez S, Maruani J, Néliat G, Caput D, Ferrara P, Soubrié P, Brelière JC, Le Fur G (1994) SR141716A, a potent and selective antagonist of the brain cannabinoid receptor. FEBS Lett 350:240-244. Medline

Robbins MJ, Calver AR, Filippov AK, Hirst WD, Russell RB, Wood MD, Nasir S, Couve A, Brown DA, Moss SJ, Pangalos MN (2001) $\mathrm{GABA}(\mathrm{B}) 2$ is essential for g-protein coupling of the GABA(B) receptor heterodimer. J Neurosci 21:8043-8052. Medline

Romano C, Yang W-L, O'Malley KL (1996) Metabotropic glutamate receptor 5 is a disulfide-linked dimer. J Biol Chem 271:2861228616. Medline

Roselli-Rehfuss L, Mountjoy KG, Robbins LS, Mortrud MT, Low MJ, Tatro JB, Entwistle ML, Simerly RB, Cone RD (1993) Identification of a receptor for gamma melanotropin and other proopiomelanocortin peptides in the hypothalamus and limbic system. Proc Natl Acad Sci U S A 90:8856-8860. Medline

Rosenzweig-Lipson S, Comery T, Marquis K, Gross J, Dunlop J (2012) 5-HT2C agonists as therapeutics for the treatment of schizophrenia. In: Novel antischizophrenia treatments (Geyer MA, Gross G, eds), pp 147-165. Berlin: Springer.

Sargent PA, Sharpley AL, Williams C, Goodall EM, Cowen PJ (1997) $5-\mathrm{HT} 2 \mathrm{C}$ receptor activation decreases appetite and body weight in obese subjects. Psychopharmacology (Berl) 133:309-312. Medline Sawaguchi T, Goldman-Rakic PS (1994) The role of D1-dopamine receptor in working memory: local injections of dopamine antagonists into the prefrontal cortex of rhesus monkeys performing an oculomotor delayed-response task. J Neurophysiol 71:515-28.

Sawaguchi T, Matsumura M, Kubota K (1990) Effects of dopamine antagonists on neuronal activity related to a delayed response task in monkey prefrontal cortex. J Neurophysiol 63:1401-1412. 
Schellekens H, van Oeffelen WE, Dinan TG, Cryan JF (2013) Promiscuous dimerization of the growth hormone secretagogue receptor (GHS-R1a) attenuates ghrelin-mediated signaling. J Biol Chem 288:181-191. CrossRef Medline

Schellekens H, De Francesco PN, Kandil D, Theeuwes WF, McCarthy T, van Oeffelen WEPA, Perelló M, Giblin L, Dinan TG, Cryan JF (2015) Ghrelin's orexigenic effect is modulated via a serotonin 2C receptor interaction. ACS Chem Neurosci. Advance online publication.

Seamans JK, Floresco SB, Phillips AG (1998) D1 receptor modulation of hippocampal-prefrontal cortical circuits integrating spatial memory with executive functions in the rat. J Neurosci 18:16131621. Medline

Shalev U, Yap J, Shaham Y (2001) Leptin attenuates acute food deprivation-induced relapse to heroin seeking. J Neurosci 21: RC129. Medline

Shalev U, Highfield D, Yap J, Shaham Y (2000) Stress and relapse to drug seeking in rats: studies on the generality of the effect. Psychopharmacology (Berl) 150:337-346. Medline

Shaw AM, Irani BG, Moore MC, Haskell-Luevano C, Millard WJ (2005) Ghrelin-induced food intake and growth hormone secretion are altered in melanocortin 3 and 4 receptor knockout mice. Peptides 26:1720-1727. CrossRef Medline

Sinha R, Garcia M, Paliwal P, Kreek M, Rounsaville BJ (2006) Stressinduced cocaine craving and hypothalamic-pituitary-adrenal responses are predictive of cocaine relapse outcomes. Arch Gen Psychiatry 63:324-331. CrossRef Medline

Somerville EM, Horwood JM, Lee MD, Kennett GA, Clifton PG (2007) 5-HT(2C) receptor activation inhibits appetitive and consummatory components of feeding and increases brain c-fos immunoreactivity in mice. Eur J Neurosci 25:3115-3124. CrossRef Medline

Suchankova P, Steensland P, Fredriksson I, Engel JA, Jerlhag E (2013) Ghrelin receptor (GHS-R1A) antagonism suppresses both alcohol consumption and the alcohol deprivation effect in rats following long-term voluntary alcohol consumption. PLoS One 8:e71284. CrossRef Medline

Sutton GM, Trevaskis JL, Hulver MW, McMillan RP, Markward NJ, Babin MJ, Meyer EA, Butler AA (2006) Diet-genotype interactions in the development of the obese, insulin-resistant phenotype of C57BL/6J mice lacking melanocortin-3 or -4 receptors. Endocrinology 147:2183-2196. CrossRef Medline

Szidonya L, Cserzö M, Hunyady L (2008) Dimerization and oligomerization of G-protein-coupled receptors: debated structures with established and emerging functions. J Endocrinol 196:435-453. CrossRef Medline

Tannenbaum GS, Lapointe M, Beaudet A, Howard AD (1998) Expression of growth hormone secretagogue-receptors by growth hormone-releasing hormone neurons in the mediobasal hypothalamus. Endocrinology 139:4420-4423. CrossRef Medline

Tao YX, Huang H, Wang ZQ, Yang F, Williams JN, Nikiforovich GV (2010) Constitutive activity of neural melanocortin receptors. In: Methods in enzymology (Conn PM, ed), pp 267-279. New York: Academic.
Thiele TE, Van Dijk G, Yagaloff KA, Fisher SL, Schwartz M, Burn P, Seeley RJ (1998) Central infusion of melanocortin agonist MTII in rats: assessment of c-Fos expression and taste aversion. Am J Physiol 274:R248-R254.

Vucetic Z, Reyes TM (2010) Central dopaminergic circuitry controlling food intake and reward: implications for the regulation of obesity. Wiley Interdiscip Rev Syst Biol Med 2:577-593. CrossRef Medline

Wellman PJ, Clifford PS, Rodriguez JA (2013) Ghrelin and ghrelin receptor modulation of psychostimulant action. Front Neurosci 7:171. CrossRef

White JH, Wise A, Main MJ, Green A, Fraser NJ, Disney GH, Barnes AA, Emson P, Foord SM, Marshall FH (1998) Heterodimerization is required for the formation of a functional $\mathrm{GABA}(\mathrm{B})$ receptor. Nature 396:679-682. CrossRef Medline

White NM (1988) Effect of nigrostriatal dopamine depletion on the post-training, memory-improving action of amphetamine. Life Sci 43:7-12. Medline

White NM (1989) Reward or reinforcement: what's the difference? Neurosci Biobehav Rev 13:181-186. Medline

Willesen MG, Kristensen P, Rømer J (1999) Co-localization of growth hormone secretagogue receptor and npy mrna in the arcuate nucleus of the rat. Neuroendocrinology 70:306-316. Medline

Williams CM, Rogers PJ, Kirkham TC (1998) Hyperphagia in pre-fed rats following oral $89-\mathrm{THC}$. Physiol Behav 65:343-346. Medline

Williams GV, Goldman-Rakic PS (1995) Modulation of memory fields by dopamine D1 receptors in prefrontal cortex. Nature 376:572575. CrossRef Medline

Wise R (2008) Dopamine and reward: the anhedonia hypothesis 30 years on. Neurotox Res 14:169-183. CrossRef Medline

Wise RA (2006) Role of brain dopamine in food reward and reinforcement. Philos Trans R Soc B Biol Sci 361:1149-1158. CrossRef Medline

Yang J, Brown MS, Liang G, Grishin NV, Goldstein JL (2008) Identification of the acyltransferase that octanoylates ghrelin, an appetite-stimulating peptide hormone. Cell 132:387-396. CrossRef Medline

Young SL, Taylor M, Lawrie SM (2015) "First do no harm." A systematic review of the prevalence and management of antipsychotic adverse effects. J Psychopharmacol (Oxf) 29:353-362. CrossRef Medline

Zheng J, Dobner A, Babygirija R, Ludwig K, Takahashi T (2009) Effects of repeated restraint stress on gastric motility in rats. Am J Physiol 296:R1358-R1365. CrossRef Medline

Zigman JM, Nakano Y, Coppari R, Balthasar N, Marcus JN, Lee CE, Jones JE, Deysher AE, Waxman AR, White RD, Williams TD, Lachey JL, Seeley RJ, Lowell BB, Elmquist JK (2005) Mice lacking ghrelin receptors resist the development of diet-induced obesity. $J$ Clin Invest 115:3564-3572. CrossRef Medline

Zigman JM, Jones JE, Lee CE, Saper CB, Elmquist JK (2006) Expression of ghrelin receptor $\mathrm{mRNA}$ in the rat and the mouse brain. J Comp Neurol 494:528-548. CrossRef Medline 